\title{
Economic Analysis for Investment of Public Sector's Automated Container Terminal: Korean Case Study
}

\author{
Yohan An ${ }^{1}$ and Namkyu Park ${ }^{2, *}$ \\ 1 Department of Finance \& Accounting, Tongmyong University, Busan 48520, Korea; accahn@tu.ac.kr \\ 2 Department of International Logistics, Tongmyong University, Busan 48520, Korea \\ * Correspondence: nkpark@tu.ac.kr; Tel.: +82-010-3575-1004
}

Citation: An, Y.; Park, N. Economic Analysis for Investment of Public Sector's Automated Container Terminal: Korean Case Study. J. Mar. Sci. Eng. 2021, 9, 459. https:// doi.org/10.3390/jmse9050459

Academic Editor: Mihalis Golias

Received: 17 March 2021

Accepted: 9 April 2021

Published: 23 April 2021

Publisher's Note: MDPI stays neutral with regard to jurisdictional claims in published maps and institutional affiliations.

Copyright: (c) 2021 by the authors. Licensee MDPI, Basel, Switzerland. This article is an open access article distributed under the terms and conditions of the Creative Commons Attribution (CC BY) license (https:// creativecommons.org/licenses/by/ $4.0 /)$.

\begin{abstract}
The purpose of this case study is to conduct an economic analysis to calculate the proper terminal capacity of automated container terminal (ACT) investment from the perspective of the public sector. As a key element of smart port, the ACT is an important terminal operating facility for import/export and transshipment cargo between countries and must have facilities with sufficient capacity to load/unload export/import cargo in a timely manner according to the user's request. Recently, the method of calculating the capacity of seaport infrastructure is changing from the method of applying the maximum capacity to the method of applying the proper capacity. Therefore, it is desirable to expand port facilities by investigating proper capacity rather than expanding port facilities based on the maximum performance. This study is a case study focusing on the new port of Busan introducing the ACT. From the perspective of national fiscal income and national economy from the ACT investment, this study determines the proper terminal capacity for each berth. As a result of economic analysis, the break-even terminal capacity to secure economic feasibility is from $544,272 \mathrm{TEU}$ of the nine berths to $600,138 \mathrm{TEU}$ of two berths applying a $2.96 \%$ discount ratio. In a sensitivity analysis considering the social discount rate and the change in the size of berths, the net present value has a positive value from a minimum of 530,000 TEU (nine berths with 1.96\% social discount ratio) to a maximum of 620,000 TEU (three berths with $3.46 \%$ social discount ratio).
\end{abstract}

Keywords: automated container terminal capacity; economic analysis; public sector

\section{Introduction}

The volume of containers around the world has increased rapidly over the decades and continues in the future [1]. Therefore, container ports using conventional handling create a serious bottleneck in the global supply network. In response to this, world-class ports such as Rotterdam, Hamburg, and Qingdao are promoting port development to cope with large-sized ships and mass freights logistics activities while simultaneously increasing port capacity and improving productivity [2]. In the era of continuous low growth after the global economic crisis and COVID-19, the port development strategy should be flexibly adjusted in cooperation with the government and the private sector, and the port development strategy should adopt the concept of the proper terminal capacity. Park and An argue that an automated container terminal (hereinafter ACT) is a representative terminal operating facility that realizes the fourth industrial revolution [3]. According to Bundesministeriums für Bildung und Forschung (BMBF) report (2016), next-generation automated container hubs will use high-end technologies such as the fifth-generation network technology (5G) and automated guided vehicles (AGVs) [4]. Nowadays, 12 are semi-automated, and 11 are fully automated of the 23 automated container terminals worldwide [3,5]. ACT has brought significant benefits to the hubs. United Nations Conference on Trade and Development (hereinafter UNCTAD) announces that ACT provides significant advantages in saving terminal labor costs, improving port capacity, reducing the energy consumption of port equipment, and enhancing the image of ports [6]. However, ACT development requires 
a high level of capital investment and also needs much maintenance cost after construction [7]. In worldwide, the port owner is still a government authority, and government authority has a responsibility to invest in port facilities, including the ACT. The investment purpose of the private sector is to maximize profit, whereas that of the public sector is to maximize social benefit. Therefore, economic evaluation of ACT development should be considered before any action is taken from the perspective of the public sector.

The purpose of this study is to measure the proper terminal capacity for each berth size that can secure the economic feasibility of the ACT in the public sector based on the port development guideline in Korea. In port development, UNCTAD requires that the economic feasibility of port development be implemented [8]. In the case of Korea, it is mandatory to evaluate the economic feasibility of port investment projects following the Korean government guidelines based on UNCTAD requirements [9]. In order to smoothly promote large-scale investment projects that the government's finances are invested in, the appropriate economic feasibility is required in advance. In the case of public projects, the larger the size of the public project is, the greater the importance of economic analysis is. A public institution that is a stakeholder in port investment intends to simultaneously analyze the appropriate rent and economic feasibility for the invested berth.

In this study, we introduce the proper terminal capacity to test the economic analysis of ACT. The proper terminal capacity is a different concept from the maximum terminal capacity that maximizes the profits of terminal operating companies (TOC) [3] and is the terminal capacity from the viewpoint of the public interest, which simultaneously considers enhancing port competitiveness and minimizing total cost. From the perspective of the public sector, if the terminal capacity is low, the investment cost for port development increases, while if the terminal capacity is high, the port competitiveness decreases due to an increase in the logistics cost burden. The government and port authority (PA) in charge of ACT development need to provide the proper terminal services without deferring and congestion due to under-supply as well as no facility idle due to oversupply. Thus, economic analysis of the proper terminal capacity due to ACT development is essential because the introduction of the proper terminal capacity can maximize the benefits of port development. The research structure of this paper is shown in Figure 1 below.

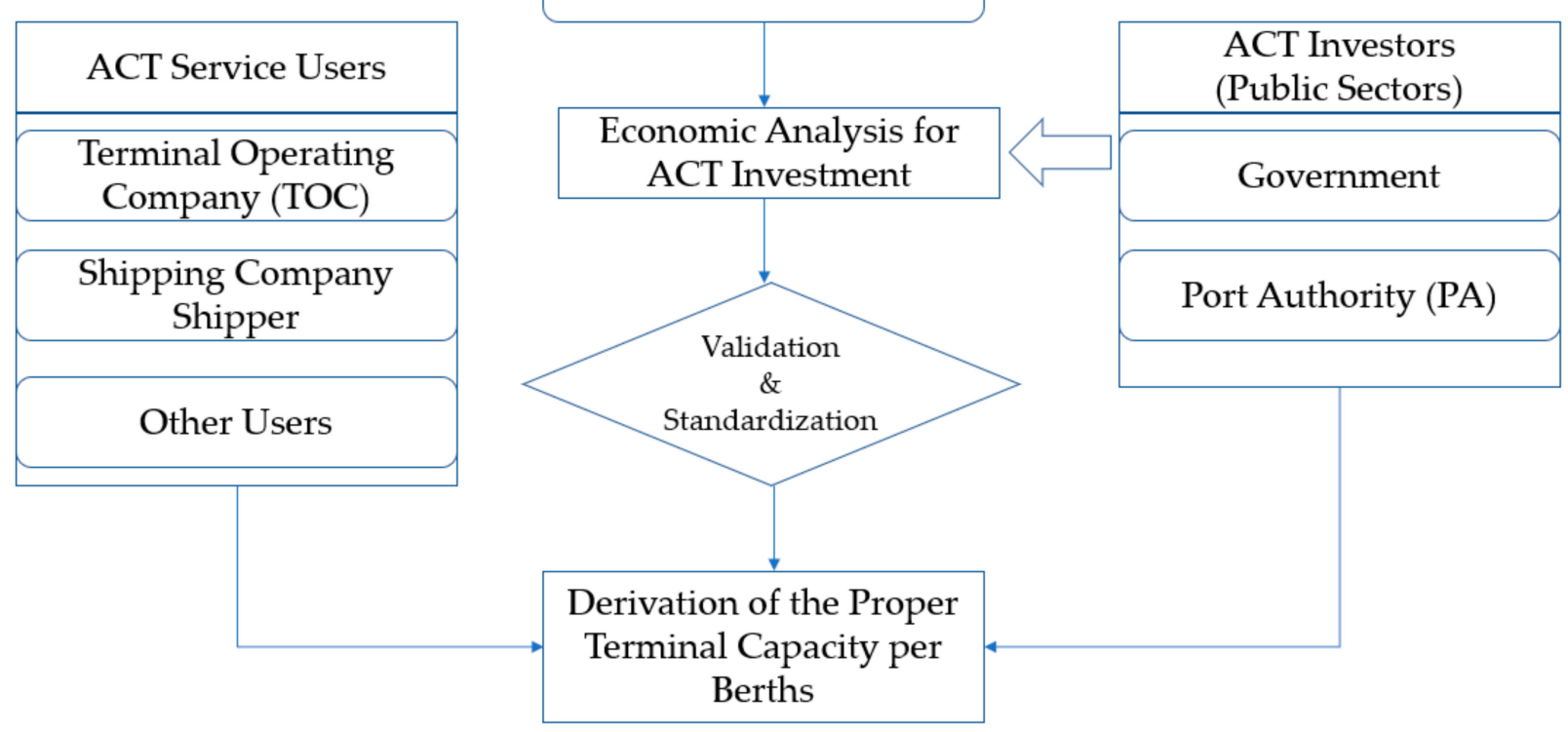

Figure 1. Research structure (Source: Author).

This study defines economic analysis as analyzing long-term net present value (LNPV) and break-even terminal capacity from the national economic perspective. Economic anal- 
ysis is a comprehensive method of analyzing economic benefits by estimating incremental benefits and costs from the perspective of the national economy based on income and expenditures directly related to national finances [10]. The scope of ACT development to economic analysis includes not only direct income and expenditure of national finances but also projects that are not directly related to national finances. Thus, this study conducts an economic analysis of the public sector.

This study is expected to make several contributions to research and practice on smart ports. First, the paper is to establish the procedure of economic analysis of the public sector regarding port investment, including ACT investment. This consists of the estimates of demand, benefits, and costs and cost-benefit analysis. However, it is a reality that it depends on the decision of the researcher as to what to select for each step as a detailed item and how to apply the parameter value. Second, this study aims to define the calculation equation in a detailed level related to benefits and costs by step and to define how to apply the values of parameters on the equation. The uniqueness of this study is that the change in net present value (NPV) can be observed according to the change in the number of berths, the change in berth capacity, and the change in social interest rate. Thus, this study expects to provide a useful method and procedure for economic analysis in investing in ACT development.

\section{Materials and Methods}

\subsection{Literature Review}

Park and Park defines ACT as a terminal that automates some or all of the core processes of container terminal operation, such as ship terminal, transfer, and yard equipment [11]. In the view of the operation, the ACT is defined as terminals that are operated without direct human interaction of $100 \%$ [12]. ACT can increase productivity by 10 to $35 \%$ while reducing the number of workers required by $45 \%$ or more and operating costs by 25 to $55 \%$, as well as reducing carbon emissions by $50 \%$ or more [13]. According to Thomas Koch (2003), the ACT investment cost is about $116 \%$ higher than that of the existing container terminal, but the operating cost is about $16 \%$ lower than that of the existing container terminal, so it is more economical than the existing container terminal from 3 to 4 years after ACT operation [14]. However, the investment in ACTs requires large capital as well as the construction cost is very high. In addition, the cost of repair or reconstruction is also great after completion. Thus, it is very important to make a reasonable economic analysis of the investment of ACTs before construction or transformation [7].

The terminal capacity should be considered not only the internal conditions of the system but also the conditions of the external environment. In the whole process, each entity has different intrinsic abilities, so the ability of the lowest entity among the abilities of multiple entities should be considered as the proper capability of the system as a whole. Moreover, UNCTAD presents that performance analysis is carried out to determine the effect of different levels of port capacity on the level of service provided to port's customers [15]. Park and An state that the proper port service is defined as the level of service at which port service users are satisfied or do not move to other alternative ports due to service dissatisfaction [3]. Therefore, in the view of the public sector, the proper terminal capacity means that the terminal can actually handle regardless of the service level, and the terminal capacity from a public interest point of view that simultaneously considers enhancing port competitiveness and minimizing total cost.

The investment objective of the public sector is to maximize social benefit, unlike that of the private sector. Therefore, an economic analysis comparing benefit and cost is used to evaluate the investment in many types of public investment such as highway, port, and railways, and is a very useful measure of desirability for projects on the government. In most countries, the port owner is still the government authority. Thus, the government authority has a responsibility to find the lowest cost for transportation freights through the ports and should protect port users at the same time [16]. Therefore, investment efficiency should be promoted through objective and reliable economic evaluation for large-scale 
public investment projects. Nowadays, the economic feasibility evaluation of the port investment project is being used based on UNCTAD's Appraisal of Port Investment [8]. Following the UNCTAD, the Korean government presents Standard Guideline of Preliminary Feasibility Studies for Projects in the port development [9], and all port investment projects undertaken in Korea must follow the standard economic evaluation analysis presented in this guideline.

\subsection{Economic Analysis Method}

The main focus of this study is to analyze the benefits and optimized handling volume (or the proper terminal capacity) of the ACT development project from the perspective of public sectors such as the port authority and central government, port organizers, and port service users. In the case of economic analysis, the scope of the project to be analyzed is not limited to projects that are directly attributed to national financial income and expenditure. The economic effect of ACT investment can be quantified, and at the same time, the benefits can be measured in currency. In the case of the ACT investment project, the applicable benefits of ACT are presented in various ways since the economic benefits are different depending on the characteristics of the port. In addition, it is difficult to establish a clear criterion for classifying the characteristics of a port because several facilities are organically combined and functioning in a complex manner. This study selects the three sectors that will benefit most from ACT development: (1) terminal operating companies (TOC), (2) shipping companies and shippers, and (3) other port users. UNCTAD and the Korean government guideline suggest that the important point in the case of the port development project is to define benefit and cost. The benefits of a port development project can be classified into two groups: (1) direct benefits to the port and port facility users and (2) intangible (indirect) benefits [8,9]. Thus, the method of calculating the benefits of ACT development has to be carried out with Equation (1) based on UNCTAD and the Korean government guideline.

Benefits of ACT development $=$ Direct benefits + Indirect benefits - Total investment cos ts

The NPV of investments is the excess of the present value of future cash flow returns over the initial investment (see Equation (2)). A positive NPV indicates that the projected earnings generated by a project or investment in present values exceed the anticipated costs, also in present values. It is assumed that an investment with a positive NPV will be profitable, and an investment with a negative NPV will result in a net loss.

$$
\mathrm{NPV}=\sum_{n=1}^{N} \frac{B_{t}}{(1+r)^{n}}-\sum_{n=1}^{N} \frac{C_{t}}{(1+r)^{n}}
$$

In Equation (2), total benefits $\left(B_{t}\right)$ mean both direct benefits and indirect benefits on year $t$ perceived by the ACT development. Cost $\left(C_{t}\right)$ is total investment costs to develop ACT on year $t$. The weighted average cost of capital $(r)$ is the discount rate.

\subsection{Procedure of Calculating Direct Benefits}

Calculation of the direct benefits is based on financial analysis of ACT development. According to Korean government guidelines [9], financial analysis refers to analyzing the profitability of the business by calculating the financial costs and income of the entity performing the business.

Direct benefits $\left(D B_{t}\right)$ that are measured as revenue and directly attributed to the national finances according to port facility investment can be classified into rent fee income $\left(R I_{t}\right)$ and port facility usage fee income $\left(P F U F_{t}\right)$.

$$
D B_{t}=R I_{t}+P F U F_{t}
$$

Rent fee income $\left(R I_{t}\right)$ is the largest income item generated by ACT development. The calculation system of ACT rent fee is divided into three types: fixed-rate system, mini-max 
rate system, and shared revenue system [17]. According to Notteboom [18], most of the world's major ports, including Japan, Taiwan, the Netherlands, Germany, and the United States, have introduced a fixed-rate system and are regularly raising rent fees to reflect the inflation rate. For rental fee income, the annual inflation rate is applied by calculating the rental fee for each berth, considering the berth length and twenty-feet ground slots (TGS) as a fixed value. In this study, the standard rent fee is calculated by distributing $40 \%$ of the total rental fee paid by TOC on the basis of the berth and $60 \%$ on the basis of TGS following Korean government guidelines [9].

$$
\begin{aligned}
\text { Standard Rent Fee } t & =\frac{\sum_{n=1}^{n=k} \text { individual rent fee }}{n} \\
& =\text { Quay Wall Rent Fee }+ \text { TGS Rent Fee } \\
& =(0.4 \times \text { Average Rent Fee })+(0.6 \times \text { Average Rent Fee })
\end{aligned}
$$

The standard berth length is considered to be $350 \mathrm{~m}$ per berth which is the standard port construction criteria in Korea [19], and the TGS per berth meter is 10.66, which is derived average TGS per meter of other terminals. Therefore, the rent fee income per berth is calculated as the sum of the standard rent fee per quay length $\left(S A Q L_{t}\right)$ multiplied by $350 \mathrm{~m}$ and the standard rent fee per TGS $\left(S T G S_{t}\right)$ multiplied by the designed TGS 10.66 and $350 \mathrm{~m}$ as following Equation (5).

$$
R I_{t}=\left(S A Q L_{t} \times 350 \text { meters }+S T G S_{t} \times 10.66 \times 350 \text { meters }\right) \times \text { Inflation ratio }
$$

Port facility usage fee income is calculated by multiplying the sum of average freight charge $(F)$ per berth, average exclusive pier usage fee (EPUF) per berth composed by warehouse and yard usage fees, special warehouse usage fees such as silo and cold storage, and apron usage fees, average ship arrival/departure fee $(S A D F)$ per berth, average berth fee $(B F)$ per berth, and average anchorage fee $(A F)$ per berth by the number of berths converted based on the berth length of $350 \mathrm{~m}\left(N B_{350 \mathrm{~m}}\right)$. In addition, if the quantity of freights is changed on the basis of 650,000 TEU per berth, the port facility fee is proportionally adjusted by the changed rate.

$$
P F U F_{t}=\left(F_{b}+E P U F_{b}+S A D F_{b}+B F_{b}+A F_{b}\right) \times N B_{350 \mathrm{~m}}
$$

\subsection{Procedure of Calculating Indirect Benefits}

Economic analysis selects the main factors that can create social added value through the private sector as indirect benefits, even if they are not directly attributable to national finances. According to economics approaches, economic benefits are surplus. In other words, the change in surplus is reviewed from the perspective of an increase in revenue or a decrease in cost through ACT development. In the case of port development, the surplus can be regarded as a port-user benefit. Port users are composed of shippers, ship owners, and logistics companies. Therefore, the increase in benefits such as reduction in port delays due to increased investment in port facilities, increase in port productivity, reduction in ship waiting costs, reduction in port turnaround time, and reduction in cargo handling fees ultimately increase the consumer surplus of port users.

In the case of ACT development, the economic benefits incurred according to the characteristics of the target port are different. In this study, the three major indirect benefits that are expected to have the greatest benefit through the construction of ACT are classified into the added value of the TOC $\left(V A T O C_{t}\right)$, the added value of the port service users such as shippers and shipping company $\left(V A P S U_{t}\right)$ and the added value of other users such as port-related industries $\left(V A O U_{t}\right)$. The added value of other port users is expressed by the following Equation (7), summing all indirect benefits of port-related workers.

$$
\text { Indirect Benefits } t=\left(\text { VATOC }_{t}+\text { VAPSU }_{t}+\text { VAOU }_{t}\right)
$$


First, as a proxy of the added value of TOC $\left(\operatorname{VATOC}_{t}\right)$, net present value is applied by discounting the investment capital, operating cash flow, and financial cash flow for 30 years reflecting the economic life of port structures [9] and each berth size/loading capacity at a financial discount rate of $4.5 \%$ presented in Equation (8).

$$
\text { VATOC }_{t}=-I_{0}+\sum_{n=1}^{30} \frac{C F_{30}}{(1+0.045)^{30}}
$$

The added value of the port service users $\left(V A P S U_{t}\right)$ is largely attributed to the reduction in ship waiting costs $\left(W C_{t}\right)$, fuel costs $\left(F U E L_{t}\right)$ and cargo inventory costs $\left(I N V_{t}\right)$.

$$
\operatorname{VAPSU}_{t}=\left(W C_{t}+F U E L_{t}+I N V_{t}\right)
$$

The reduction in waiting costs is calculated by multiplying the fixed daily cost by the exchange rate and the number of waiting days based on 5500TEU as below. According to port construction criteria proposed by the Korean government [19], the standard criteria of container port should be $15 \mathrm{~m}$ depth and $350 \mathrm{~m}$ long quay for 5500TEU container ship.

$$
D C_{t}=(\text { Daily Fixed Cost } \times \text { Exchange Rate } \times \text { Waiting Days })
$$

The fuel cost reduction effect is calculated by multiplying the daily fuel cost per ton by the number of waiting days and the fuel consumption of the generator per ton per day based on 5500TEU.

$$
\text { FUEL } L_{t}=\left(\text { Daily Fuel Cost }_{\text {ton }} \times \text { Waiting Days } \times \text { Generator Fuel Consumption } \text { ton }\right)
$$

The inventory cost reduction effect is the product of daily inventory cost multiplied by the exchange rate and the number of waiting days.

$$
I N V_{t}=(\text { Daily Inventory Costs } \times \text { Exchange Rate } \times \text { Waiting Days })
$$

Indirect benefits of other port users $\left(V A O U_{t}\right)$ from the introduction of the new ACT are considered to be the pilotage fee, towage fee, and other fees, including line handling fee, lashing fee, and tallying fee.

$$
V_{A O U}=\left(P F_{t}+T F_{t}+O F_{t}\right)
$$

The pilotage fee $\left(P F_{t}\right)$ is calculated by multiplying the average incoming and outgoing ship tonnage by the arrival/departure unit price by the number of arrival/departure times per berth.

$$
\begin{aligned}
& P F_{t}=(\text { Avg In\&Out ship tonnage } \times \text { Arrival\&Departure Unit Price } \\
& \times \text { Arrival\&Departure Count per Berth })
\end{aligned}
$$

The towage fee $\left(T F_{t}\right)$ is calculated by multiplying the basic usage time by the arrival /departure unit price by the number of vessels used and the number of arrival/departure per berth.

$$
\begin{aligned}
& \mathrm{TF}_{t}=(\text { Basic Usage Time } \times \text { Arrival\&Departure Unit Price } \times \text { Ship Usage Count } \\
& \times \text { Arrival\&Departure Count per Berth })
\end{aligned}
$$

The other fees, including line handling fee, lashing fee, and tallying fee, are calculated by multiplying the arrival/departure unit price by the number of arrival/departure times per berth.

$$
O F_{t}=(\text { Arrival\&Departure Unit Price } \times \text { Arrival\&Departure Count per Berth })
$$




\subsection{Procedure of Calculating Total Investment Costs}

The construction of ACT requires much capital investment for all related stakeholders, including the government, port authority (PA), and TOC $[3,20]$. Total investment costs $\left(T I C_{t}\right)$ are defined as an estimate of the expected cost of the project based on appropriate assumptions about the construction cost of the project, the economic efficiency of the ACT based on marketability, and future funding costs, including interest rates. Therefore, total investment costs consist of construction cost $\left(C C_{t}\right)$, annual operation cost $\left(O C_{t}\right)$, interest $\operatorname{cost}\left(I C_{t}\right)$ and reinvestment and residual value $\left(R R_{t}\right)$.

Construction cost, including labor fee, is calculated by ACT investment per berth, and operating cost is calculated by applying $2 \%$ of the cumulative investment per project [9]. Interest cost is calculated by applying interest as the average bond interest rate issued by Busan Port Authority (BPA) for three years [21], assuming that the total investment amount was raised through borrowing. Reinvestment and residual value assume reinvestment at the end of the economic life, and the base price for reinvestment is calculated as the amount reinvested by reflecting the inflation rate from the initial investment to the time of reinvestment [9]. Thus, total investment costs are expressed in Equation (15).

$$
T I C_{t}=C C_{t}+O C_{t}+I C_{t}+R R_{t}
$$

\section{The Premise of Analysis for Case Study}

\subsection{ACT Layout}

The vertical block type of ACT is designed with the aim of improving handling productivity. The feature is that the AGV enters lanes between blocks, minimizing the movement of the automatic stacking crane (ASC) and maximizing Container Yard (CY) handling productivity. In order for AGV to travel between blocks, the interval between blocks must be $21 \mathrm{~m}$, and in this situation, a cantilever automatic transfer crane (CATC) is used.

Figure 2 is the layout of ACT in The New Port of Busan (Phase 2-5, 2-6). One AGV path is placed in seven blocks. In addition, a rescue road must be secured as containers stacked in blocks may fall over. The width of the rescue road is set to $6 \mathrm{~m}$, one for two blocks. Otherwise, the width between blocks is $4.0 \mathrm{~m}$. If the width between blocks is reflected in the design, 24 blocks can be placed. Since the total required slots are 62,310 TGS, this is allocated to 24 blocks. As a result, 2596 total slots in the twenty-foot equivalent unit (TEU) unit are required per block, as shown in Figure 2. Stacking $20^{\prime}$ containers in 10 rows and six tiers, which is decided by ASC specification, 43 bays required as shown in Figure 2 . 


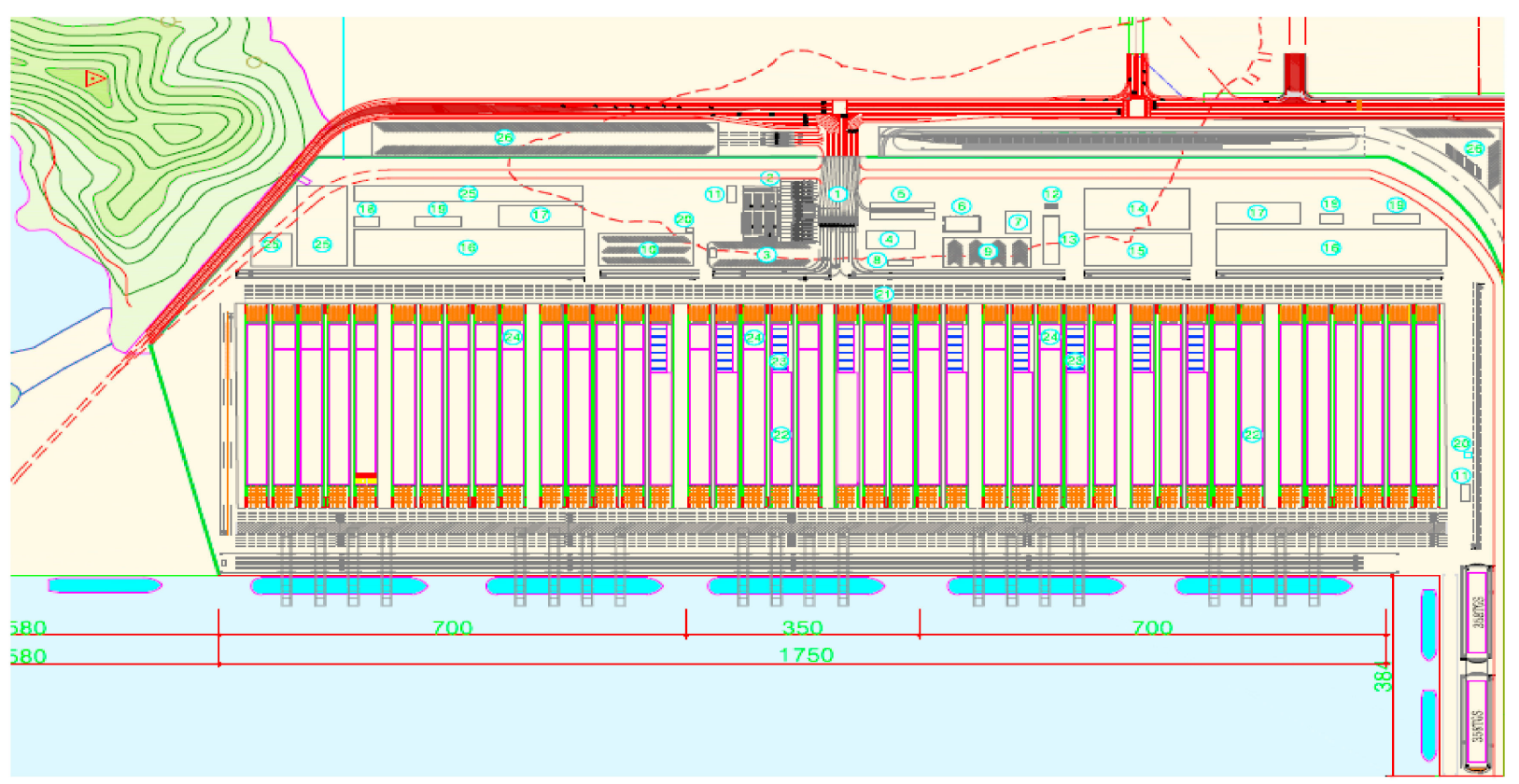

Figure 2. Automated container terminal (ACT) layout with 5 berths (Source: Author).

\subsection{Assumptions Applied for Economic Analysis}

The base year for analysis of this study is set to 1 January, 2020, and the analysis target period applies 30 years from 1 January, 2020 to 1 January, 2049 following the Korean government guideline [9]. The most important factor in establishing an estimated period for the economic costs and benefits is to determine the economic life year of critical facilities and equipment. In port investment, since the economic life year of each major facility and equipment is different, the average economic life year is calculated by weighting the investment cost of each facility, and the value is set as the estimated period. According to the Korean port investment evaluation guideline [9], the economic life of port structures and equipment is usually based on 15 to 30 years, and the economic life estimation period is used differently for each project and purpose.

The capital structure assumes no equity capital investment and borrowing through the issuance of all bonds. Annually, the balance of the rent and port facility usage income minus interest expenses is reimbursed, and the size of the berths subject to analysis consists of five types: nine berths, five berths, four berths, three berths, and two berths. According to the Busan New Port Development Plan, Port Authority (PA) plans to sell a maximum nine berths, 5 berths, 4 berths, 3 berths, and a minimum of two berths to the private sector. In addition, the berth division is to reveal the effect due to the scale of the economy as the number of berths increase. Among the five types, five berths are taken as analysis targets when introducing the ACT terminal. The investment amount for each model is calculated by normalizing the actual and expected investments of phases $2-5$ ( 3 berths) and 2-6 ( 2 berths) of the west container terminal in Busan New Port as a substitute terminal. It is assumed that the effect of value-added tax is ignored, and the construction investment is completed on June 30,2019. Construction cost is converted to the value at the end of 2020, and it is regarded as the returnable investment cost.

Discount rates are divided into two categories: social discount rates and financial (private) discount rates, and although economists have different perspectives, most insist that social discount rates should be lower than private discount rates [22]. The social discount rate serves as a criterion for evaluating the potential value of various goods during each period and can be defined as the rate of change in value by the period of the value scale. Therefore, in this study, the social discount rate is applied because the economic analysis is performed from the perspective of the public sector. The social discount rate is $2.96 \%$, plus the business risk compensation rate (1\%) to the 5 -year Korean government 
bond yield (1.96\%). Finally, all currency units used in this study are expressed in U.S. dollars applying the average USD-KRW exchange rate of $1132 \mathrm{KRW}$ for the last three years [23].

The sensitivity analysis shown in Table 1 is performed on the terminal volume and social discount rate. The economic analysis considers both the income of the fiscal sector and the benefits of the private sector, so the estimated rent level is calculated as a fixed value based on the current estimate, and the terminal volume, which has a significant effect on the benefit category, is calculated as the subject of sensitivity analysis. Moreover, UNCTAD and the Korean government guideline propose that two parameters that affect the acceptability of the port development project are interest rate and cargo throughput $[8,9]$.

Table 1. Sensitivity analysis criteria.

\begin{tabular}{ccc}
\hline & Review Scope & Remark \\
\hline Throughput per berth & $\begin{array}{c}530,000 \sim 630,000 \text { TEU per } \\
\text { berth }\end{array}$ & 100,000 TEU per berth \\
\hline Social discount rate & $1.96 \sim 3.96 \%$ & $0.5 \%$ p unit \\
\hline
\end{tabular}

Source: Author.

\section{Economic Analysis for Case Study: Busan New Port}

In this study, direct benefits shown in Equation (3) are income items that are directly attributed to the national finances according to ACT construction and consist of rental fee income and port facility usage fees income. Indirect benefits are shown in Equation (6) consist of the added value of the TOC, port service users (shipping companies and shippers, etc.), and other users (workers in port-related industries), which are expected to have the benefits through ACT construction. The total investment costs for ACT calculated by Equation (15) are classified into four categories; (1) construction costs, (2) annual operation cost, (3) interest cost, and (4) reinvestment and residual value.

\subsection{Estimating Direct Benefits}

The fixed rent fee system is a system in which the lessor charges the lessee a fixed amount per area or per berth for a specific period of time and is the most common method of calculating rent income [24]. The fixed rent system is most suitable for providing the maximum benefit to port construction through maximization of throughput and is the most advantageous method for rapid activation of new ports [25]. In Equation (4), for rent estimation, the annual inflation rate is applied by calculating the rent for each berth considering the quay length and TGS as a fixed value. Specifically, based on the 2019 rent of the existing ACT port, $40 \%$ is allocated to the berth length, and $60 \%$ is allocated to TGS to calculate the rent fee income. Table 2 shows the standard rent fee per terminal in Busan New Port, allocating 40\% berth length and 60\% TGS as of 2019 applied in Equation (4).

Table 2. Standard rent fee per terminal in Busan New Port.

\begin{tabular}{|c|c|c|c|c|c|}
\hline Terminal & Berth Length (m) & TGS & $\begin{array}{l}\text { Rent fee as of } 2019 \\
\text { (unit: U.S. dollars) }\end{array}$ & $\begin{array}{c}\text { Berth (40\%) } \\
\text { (unit: U.S. dollars) }\end{array}$ & $\begin{array}{c}\text { TGS }(60 \%) \\
\text { (unit: U.S. dollars) }\end{array}$ \\
\hline A & 1200 & 12,474 & $\$ 24,348,940$ & $\$ 14,609,541$ & $\$ 9,739,399$ \\
\hline $\mathrm{B}$ & 2000 & 20,824 & \multicolumn{3}{|c|}{ Excludes (private capital investment terminal) } \\
\hline $\mathrm{C}$ & 1100 & 11,940 & $\$ 29,522,968$ & $\$ 17,713,781$ & $\$ 11,809,187$ \\
\hline $\mathrm{D}$ & 1150 & 10,031 & $\$ 24,598,057$ & $\$ 14,758,834$ & $\$ 9,839,223$ \\
\hline $\mathrm{E}$ & 1400 & 12,683 & \multicolumn{3}{|c|}{ Excludes (private capital investment terminal) } \\
\hline
\end{tabular}

Source: Annual report of Busan Port Authority (2019). 
Based on the data presented in Table 3, the rent fee per berth considering the berth length of the ACT to be analyzed ( $350 \mathrm{~m}$ per berth) and the designed TGS (10.66) per $\mathrm{m}$ of the berth are shown in Table 4. Standard rent income for each berth applying both berth length and TGS is $\$ 8,176,487$, and the total estimated annual rent per berth based on equation (5) ranges from a maximum of $\$ 2,717,289,753$ to a minimum of $\$ 603,840,989$.

Table 3. Estimated material cost.

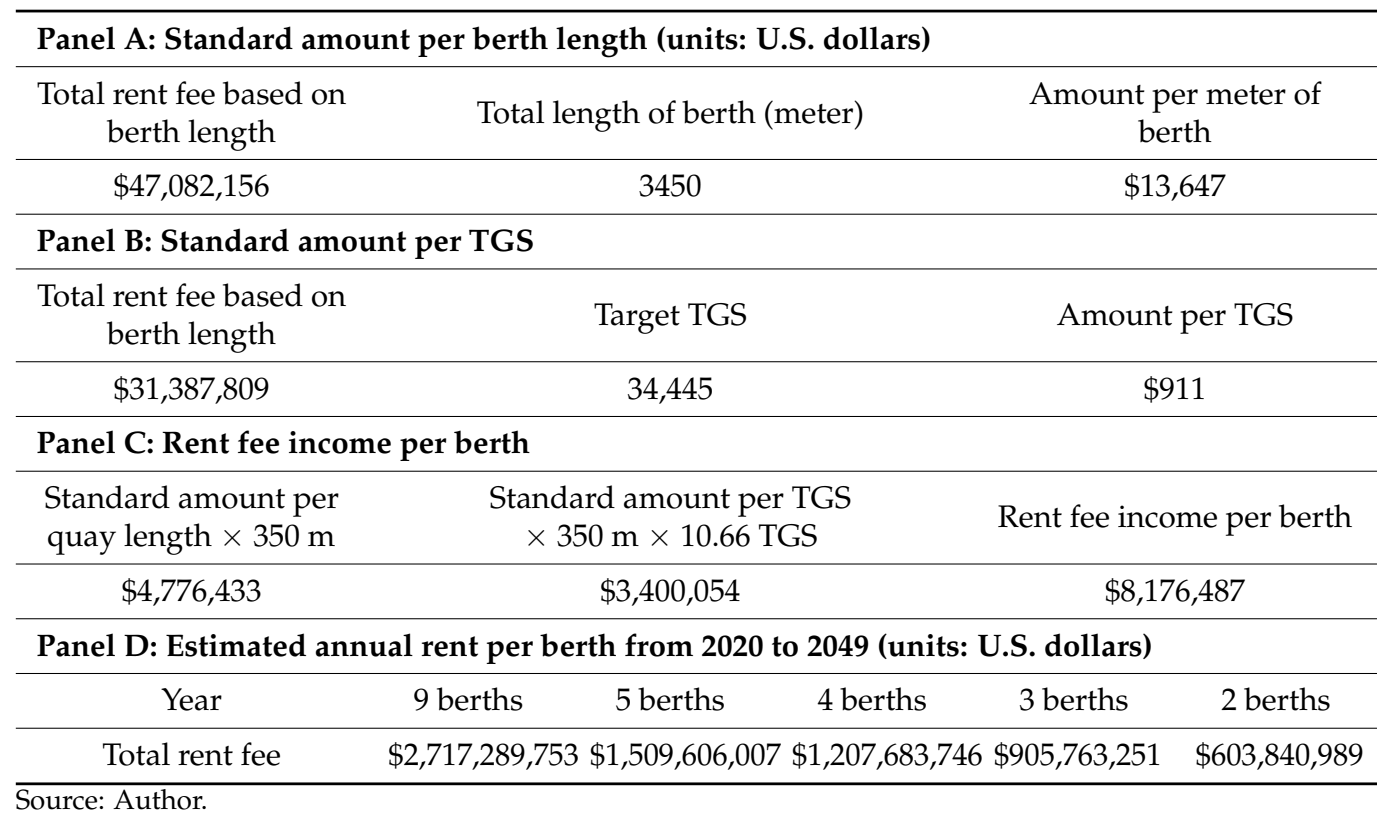

\subsection{The Income of Port Facility Usage Fee}

As the second major direct benefit item, port facility usage fee covers freight charges, exclusive use fees, ship arrival and departure fees, berth fees and anchorage fees, and freight charges apply only to import and export cargo. The amount per berth is calculated by converting the average port facility usage fee per berth for three years and then dividing the total port facility usage fee by the total number of berths based on the quay length of $350 \mathrm{~m}$. Table 4 provides the compositions of port facility usage fees following Equation (6). The three-year average port facility usage fee income is $\$ 64,810,954$, and the average port usage fee income per berth is $\$ 3,311,837$.

As a result of using Equation (6) based on the data in Table 5, the estimated amount of port facility usage fees during the analysis period is presented in Table 5 . The estimated amount of port facility usage fees by the number of berths is expected to be from a maximum of $\$ 1,306,357,774$ to a minimum of $\$ 290,300,353$. 
Table 4. Status of port facility usage in Busan New Port.

\begin{tabular}{ccccc}
\hline Panel A: Total number of berths & & & \\
\hline Terminal & $\begin{array}{c}\text { Berth Length } \\
\text { (meter) }\end{array}$ & TGS & Size & $\begin{array}{c}\text { Number of berths based on 350 m of quay } \\
\text { length }\end{array}$ \\
\hline A & 1200 & 12,474 & $840,000 \mathrm{~m}^{2}$ & 3.43 \\
\hline B & 2000 & 20,824 & $1,210,000 \mathrm{~m}^{2}$ & 3.71 \\
\hline C & 1100 & 11,940 & $688,000 \mathrm{~m}^{2}$ & 3.14 \\
\hline D & 1150 & 10,031 & $553,000 \mathrm{~m}^{2}$ & 4.00 \\
\hline E & 1400 & 12,683 & $785,000 \mathrm{~m}^{2}$ & 19.57
\end{tabular}

Panel B: The number of vessels arriving in the last three years.

\begin{tabular}{|c|c|c|c|c|c|}
\hline & 3 years ago & 2 years ago & 1 year ago & $\begin{array}{c}\text { Average of the last } 3 \\
\text { years }\end{array}$ & $\begin{array}{l}\text { Average per } \\
\text { berth }\end{array}$ \\
\hline Less than 50,000 tons & 4741 & 4708 & 4815 & 4755 & 243 \\
\hline 50,000 tons-less than 70,000 tons & 1105 & 1012 & 899 & 1005 & 51 \\
\hline 70,000 tons-less than 80,000 tons & 557 & 592 & 722 & 624 & 32 \\
\hline 80,000 tons-less than 100,000 tons & 1045 & 1169 & 1202 & 1139 & 58 \\
\hline 100,000 tons or more & 1032 & 1119 & 1220 & 1124 & 57 \\
\hline Total & 8480 & 8600 & 8858 & 8646 & 442 \\
\hline
\end{tabular}

Panel C: Port facility usage fee of Busan New Port for the last 3 years (units: U.S. dollars)

\begin{tabular}{cccccc}
\hline & 3 years ago & 2 years ago & 1 year ago & $\begin{array}{c}\text { Average of the last 3 } \\
\text { years }\end{array}$ & $\begin{array}{c}\text { Average per } \\
\text { berth }\end{array}$ \\
\hline Freight charge & $\$ 16,718,198$ & $\$ 17,404,594$ & $\$ 17,895,760$ & $\$ 17,339,223$ & $\$ 886,042$ \\
\hline Exclusive pier usage fee & $\$ 13,251$ & $\$ 15,901$ & - & $\$ 9717$ & $\$ 883$ \\
\hline Ship entry/departure fee & $\$ 34,688,163$ & $\$ 37,548,587$ & $\$ 37,935,512$ & $\$ 36,724,382$ & $\$ 1,876,325$ \\
\hline Berth fee & $\$ 9,294,170$ & $\$ 9,962,014$ & $\$ 10,984,099$ & $\$ 10,080,389$ & $\$ 515,018$ \\
\hline Anchorage fee & $\$ 204,947$ & $\$ 1,530,919$ & $\$ 236,749$ & $\$ 657,244$ & $\$ 33,569$ \\
\hline Total & $\$ 60,918,728$ & $\$ 66,462,014$ & $\$ 67,052,120$ & $\$ 64,810,954$ & $\$ 3,311,837$ \\
\hline
\end{tabular}

Source: Annual report of Busan Port Authority (2019).

Table 5. Estimated port facility usage fee from 2020 to 2049 (unit: U.S. dollars).

\begin{tabular}{cccccc}
\hline Year & 9 Berths & 5 Berths & 4 Berths & 3 Berths & 2 Berths \\
\hline Total & $\$ 1,306,357,774$ & $\$ 725,757,067$ & $\$ 580,601,590$ & $\$ 435,453,180$ & $\$ 290,300,353$ \\
\hline Source: Author. & & &
\end{tabular}

\subsection{Estimating Indirect Benefits}

In the case of port investment projects, the economic benefits arising from the characteristics of the target port are different, and thus, the applicable benefit items are also presented in a variety of ways. However, it is not easy to establish a clear standard for classifying the characteristics of a port because several facilities are organically combined to perform functions in a complex manner. In addition, for individual projects such as maintenance dredging or the construction of revetment during port operation, benefits are calculated from the viewpoint of port efficiency, which is affected by the investment of the facility, rather than the economic benefits of the facility itself.

Port users are the main body of port use and are largely composed of TOC and port service users. Declining prices such as reduction of ship waiting costs and stevedoring fees ultimately increase the surplus of port users. Applying Equation (7), this study is 
classified into the added value of the port operator, the added value of the port service users such as shippers and shipping company and the added value of other users such as port-related industries.

First, the added value in the view of TOC is measured as the NPV by applying a $4.5 \%$ financial discount rate according to the change in throughput resulting from the ACT investment, as shown in Table 6. The sum of NPV for each berth appears from $\$ 2,554,325,972$ (9 berths) to $-\$ 470,681,979$ (2 berths) applying Equation (8). Thus, the added value of TOC calculated as the sum of NPV for each berth is $\$ 1,129,772,967$.

Table 6. Net present value (NPV) per berth considering changes of the unloading volume (unit: U.S. dollars).

\begin{tabular}{|c|c|c|c|c|c|c|}
\hline & & \multicolumn{5}{|c|}{ Applying $4.5 \%$ Discount Ratio } \\
\hline & & 9 Berths & 5 Berths & 4 Berths & 3 Berths & 2 Berths \\
\hline \multirow{12}{*}{$\begin{array}{c}\text { Throughput per } \\
\text { berth } \\
\text { (TEU) }\end{array}$} & 550,000 & $(\$ 61,402,827)$ & $(\$ 168,899,293)$ & $(\$ 162,064,488)$ & $(\$ 143,135,159)$ & $(\$ 110,226,148)$ \\
\hline & 560,000 & $(\$ 2,496,466)$ & $(\$ 136,366,608)$ & $(\$ 136,008,834)$ & $(\$ 121,906,360)$ & $(\$ 94,849,823)$ \\
\hline & 570,000 & $\$ 56,248,233$ & $(\$ 103,984,099)$ & $(\$ 110,060,071)$ & $(\$ 102,437,279)$ & $(\$ 80,881,625)$ \\
\hline & 580,000 & $\$ 114,969,081$ & $(\$ 71,751,767)$ & $(\$ 84,258,834)$ & $(\$ 83,053,004)$ & $(\$ 67,904,594)$ \\
\hline & 590,000 & $\$ 173,655,477$ & $(\$ 39,719,965)$ & $(\$ 58,607,774)$ & $(\$ 63,753,534)$ & $(\$ 55,001,767)$ \\
\hline & 600,000 & $\$ 232,185,512$ & $(\$ 7,783,569)$ & $(\$ 33,106,890)$ & $(\$ 44,541,519)$ & $(\$ 42,157,244)$ \\
\hline & 610,000 & $\$ 290,960,247$ & $\$ 24,107,774$ & $(\$ 7,661,661)$ & $(\$ 25,443,463)$ & $(\$ 29,373,675)$ \\
\hline & 620,000 & $\$ 349,499,117$ & $\$ 56,024,735$ & $\$ 17,787,102$ & $(\$ 6,426,678)$ & $(\$ 16,638,693)$ \\
\hline & 630,000 & $\$ 408,287,986$ & $\$ 87,827,739$ & $\$ 43,150,177$ & $\$ 12,604,240$ & $(\$ 3,918,728)$ \\
\hline & 640,000 & $\$ 466,773,852$ & $\$ 119,697,880$ & $\$ 68,443,463$ & $\$ 31,608,657$ & $\$ 8,796,820$ \\
\hline & 650,000 & $\$ 525,645,760$ & $\$ 151,480,565$ & $\$ 93,840,989$ & $\$ 50,526,502$ & $\$ 21,473,498$ \\
\hline & Total & $\$ 2,554,325,972$ & $(\$ 89,366,608)$ & $(\$ 368,546,821)$ & $(\$ 495,957,597)$ & $(\$ 470,681,979)$ \\
\hline
\end{tabular}

Second, the added value of port service users (shipping companies and shippers, etc.) is the reduction of waiting costs, fuel cost reduction (added value of the above shipping company), and inventory cost reduction (added value of the shipper). Table 7 provides the details of the added value of port service users.

When calculating waiting costs using Equation (10), the fixed cost per day is calculated using the Drewry Maritime Research report (2013) [26]. The saving amount per berth of deferral costs is $\$ 279,803$. In applying Equation (11) to calculate fuel cost savings, waiting days per berth have to be considered. Among the terminals, terminal $C$ and terminal $E$ for which information on the number of waiting vessels is excluded, and the data provided by BPA-NET [27] are used for the number of inbound vessels. The ship's fuel cost is the average price of a ship's diesel for three years, as suggested by Petronet of Korea National Oil Corporation [28]. The fuel cost savings per berth are $\$ 60,712$, shown in panel D of Table 7. When calculating the inventory cost reduction effect applying Equation (12), the daily inventory cost is calculated by applying the inventory rate index [29] to the average daily amount of domestic exports and imports in 2018. As a result, the inventory cost savings per berth are $\$ 42,264,352$. 
Table 7. Calculating three major components of the added value of port services users.

\begin{tabular}{|c|c|c|c|c|c|}
\hline \multicolumn{6}{|c|}{ Panel A: Calculating deferral cost savings (the added value of shipping companies.) } \\
\hline & Fixed cost per day & $\begin{array}{l}\text { Exchange rate } \\
\text { (USD/KRW) }\end{array}$ & $\begin{array}{l}\text { Waiting days } \\
\text { (day) }\end{array}$ & $\begin{array}{l}\text { Savings per berth } \\
\text { (unit: U.S. dollar) }\end{array}$ & Remark \\
\hline $\begin{array}{l}\text { 5500TEU } \\
\text { standard }\end{array}$ & $\$ 22,846$ & 1132 & 12.26 & $\$ 279,803$ & $\begin{array}{c}\text { Number of flight } \\
\text { days/crew } \\
\text { fee/insurance fee, etc. }\end{array}$ \\
\hline \multicolumn{6}{|c|}{ Panel B: Waiting days per berth } \\
\hline Terminal & $\begin{array}{l}\text { Annual average } \\
\text { number of ships } \\
\text { arriving (ship) }\end{array}$ & $\begin{array}{l}\text { Number of berths } \\
\text { based on } 350 \mathrm{~m} \\
\text { berth }\end{array}$ & $\begin{array}{l}\text { Average waiting } \\
\text { time per ship } \\
\text { (hour) }\end{array}$ & $\begin{array}{l}\text { Number of ships } \\
\text { waiting (ship) }\end{array}$ & $\begin{array}{l}\text { Total waiting time } \\
\text { (hour) }\end{array}$ \\
\hline A & 1446 & 3.43 & 9.00 & 41.00 & 369 \\
\hline B & 2600 & 5.71 & 10.10 & 267.00 & 2697 \\
\hline $\mathrm{D}$ & 1524 & 3.29 & 9.40 & 63.00 & 592 \\
\hline Total & 8417 & 12.43 & - & - & 3658 \\
\hline
\end{tabular}

Panel C: Calculating average waiting times and days

\begin{tabular}{lccc}
\hline Total waiting time & Number of berths based on $350 \mathrm{~m}$ berth & $\begin{array}{c}\text { Average waiting } \\
\text { time }\end{array}$ & $\begin{array}{c}\text { Average number of } \\
\text { waiting days }\end{array}$ \\
\hline $3658 \mathrm{~h}$ & 12.43 berths & $294.31 \mathrm{~h}$ & $12.26 \mathrm{~h}$ \\
\hline
\end{tabular}

Panel D: Calculating fuel cost savings (the added value of shipping companies)

Unit price per ton of fuel cost (U.S. Generator fuel dollars/ton) Waiting days (day) consumption (ton/1 day)

$\begin{array}{lllll}\begin{array}{l}\text { 5500TEU } \\ \text { standard }\end{array} & \$ 1238 & 12.26 & 4 & \$ 60,712\end{array}$

Panel E: Calculating inventory cost savings (the added value of the shipper)

\begin{tabular}{cccc} 
Inventory cost per day & Exchange ratio(USD/KRW) & Waiting days (day) & Savings per berth \\
\hline$\$ 37,336$ & 1132 & 12.26 & $\$ 42,264,352$ \\
\hline
\end{tabular}

The estimate of the added value of port service users (shipping companies and shippers, etc.) in Table 8 is based on 650,000 TEU per berth, and the benefit of port service users is proportionally adjusted by the changed rate when the quantity of goods changes. During the analysis period, the expected additional value of the use of port services is estimated at a maximum of $\$ 265,128,092$ to a minimum of $\$ 58,918,728$.

Table 8. Estimating the added value of port services users from 2020 to 2049 (unit: U.S. dollars).

\begin{tabular}{cccccc}
\hline Year & 9 Berths & 5 Berths & 4 Berths & 3 Berths & 2 Berths \\
\hline Total & $\$ 265,128,092$ & $\$ 147,293,286$ & $\$ 117,835,689$ & $\$ 88,373,675$ & $\$ 58,918,728$ \\
\hline
\end{tabular}

Source: Author.

The added value of other port users (port-related workers, etc.) is measured in terms of pilotage fee, towage fee, and other fees, including line handling fees, lashing fees, and tallying fees based on Equation (13). Other items, such as vessel refueling, container repair, water supply, transportation, hold cleaning, and vessel waste treatment, are not necessarily generated, and the rates are also very diverse, so they are excluded from the subject of discussion.

Table 9 shows the calculation of three components of the added value of port-related workers: (1) pilotage fee; (2) towage fee; and (3) other fees, including line handling fees, lashing fees, and tallying fees. 
Table 9. Estimating the added value of port services users.

\begin{tabular}{|c|c|c|c|c|c|c|c|}
\hline \multicolumn{8}{|c|}{ Panel A: Calculating pilotage fee } \\
\hline & & $\begin{array}{l}\text { Average } \\
\text { inbound } \\
\text { vessel } \\
\text { tonnage } \\
(\mathrm{G} / \mathrm{T})\end{array}$ & \multicolumn{2}{|c|}{$\begin{array}{l}\text { Unit price } \\
\text { (U.S. dollars) }\end{array}$} & $\begin{array}{l}\text { Number of arrivals and } \\
\text { departures per berth }\end{array}$ & \multicolumn{2}{|c|}{$\begin{array}{l}\text { Estimated amount per berth } \\
\text { (U.S. dollars) }\end{array}$} \\
\hline \multirow{2}{*}{ Pilotage fee } & Arrival & \multirow{4}{*}{$44,082 *$} & \multicolumn{2}{|l|}{121} & \multirow{4}{*}{442} & \multicolumn{2}{|c|}{$\$ 53,482$} \\
\hline & Departure & & \multicolumn{2}{|l|}{121} & & \multicolumn{2}{|c|}{$\$ 53,482$} \\
\hline \multirow{2}{*}{ Pilot boat fee } & Arrival & & \multicolumn{2}{|l|}{427} & & \multicolumn{2}{|c|}{$\$ 188,734$} \\
\hline & Departure & & \multicolumn{2}{|l|}{427} & & \multicolumn{2}{|c|}{$\$ 188,734$} \\
\hline & & & \multicolumn{3}{|c|}{ Total } & \multicolumn{2}{|c|}{$\$ 956,549$} \\
\hline & Terminal & & \multicolumn{5}{|c|}{ Tonnage of ships entering and departing (GT) for 3 years } \\
\hline & A & & \multicolumn{5}{|c|}{$211,240,108$} \\
\hline & B & & \multicolumn{5}{|c|}{$388,736,558$} \\
\hline & $\mathrm{C}$ & & \multicolumn{5}{|c|}{$178,207,054$} \\
\hline & $\mathrm{D}$ & & \multicolumn{5}{|c|}{$167,114,903$} \\
\hline & E & & \multicolumn{5}{|c|}{$198,108,124$} \\
\hline & Total & & \multicolumn{5}{|c|}{$1,143,406,747$} \\
\hline \multicolumn{3}{|c|}{ Number of arrivals and departures in 3 years } & \multicolumn{5}{|c|}{25,938} \\
\hline \multicolumn{3}{|c|}{ Average tonnage } & & & 44,082 & & \\
\hline * Ship arrival and & parture status b & onnage by yea & in Busan New Por & & & & \\
\hline & & 3 years ago & 2 years a & & 1 year ago & $\begin{array}{c}\text { Average of } \\
\text { the last } 3 \\
\text { years }\end{array}$ & $\begin{array}{l}\text { Average per } \\
\text { berth }\end{array}$ \\
\hline Less than 5 & 000 tons & 4741 & 4708 & & 4815 & 4755 & 243 \\
\hline 50,000 tons-less & an 70,000 tons & 1105 & 1012 & & 899 & 1005 & 51 \\
\hline 70,000 tons-less & an 80,000 tons & 557 & 592 & & 722 & 624 & 32 \\
\hline 80,000 tons-less t & n 100,000 tons & 1045 & 1169 & & 1202 & 1139 & 58 \\
\hline 100,000 tor & or more & 1032 & 1119 & & 1220 & 1124 & 57 \\
\hline To & & 8480 & 8600 & & 8858 & 8646 & 442 \\
\hline & & & Panel B: Calcula & ting towage & & & \\
\hline & & $\begin{array}{l}\text { Basic usage } \\
\text { time }\end{array}$ & $\begin{array}{l}\text { Unit price (U.S. } \\
\text { dollar) }\end{array}$ & $\begin{array}{l}\text { Number of } \\
\text { ships used }\end{array}$ & $\begin{array}{l}\text { Number of arrivals and } \\
\text { departures per berth }\end{array}$ & $\begin{array}{r}\text { Estimated ar } \\
\text { (U.S }\end{array}$ & $\begin{array}{l}\text { ount per berth } \\
\text { lollar) }\end{array}$ \\
\hline Towage fee & Arrival & $2 \mathrm{~h}$ & $\$ 972$ & 2 ships & 442 & & 734 \\
\hline & Departure & & $\$ 972$ & & & & 734 \\
\hline & & & otal & & & & 468 \\
\hline & & Panel C: C & lculating line han & dling, lashin & and tally fees & & \\
\hline & & $\begin{array}{l}\text { Unit price } \\
\text { (U.S. dollar) }\end{array}$ & Number of & arrivals and $c$ & partures per berth & $\begin{array}{r}\text { Estimated ar } \\
\text { (U.S }\end{array}$ & $\begin{array}{l}\text { ount per berth } \\
\text { lollar) }\end{array}$ \\
\hline Line handling fee & Arrival & $\$ 41$ & & 442 & & & 112 \\
\hline & Departure & $\$ 41$ & & 442 & & & 112 \\
\hline & Lashing fee & & & 442 & & & 875 \\
\hline & Tallying fee & & & 442 & & & 610 \\
\hline & & & otal & & & & 790 \\
\hline
\end{tabular}

Using Equation (14), the pilotage fee is calculated by multiplying the average number of the tonnage of ships arrival and departure the Busan New Port [27] and the publicly announced rate of pilotage fee by the Busan Harbor Pilot's Association [30] and the average number of arrivals and departures per berth at the Busan New Port over the past three years [27]. The estimated pilotage fee per berth is $\$ 956,549$.

In Panel B of Table 9, the towage fee is the amount obtained by multiplying the basic usage time and basic unit price of arrival/departure times by the number of vessels used and the number of entry and exit times per berth based on Equation (15). As a result, the estimated towing fee per berth is $\$ 377,468$. 
Other fees composing line handling fee, lashing fee, and inspection fee are the amount obtained by multiplying the basic unit price of each usage fee by the number of arrivals and departures per berth, and the total amount is $\$ 882,790$ presented in panel C of Table 9.

Table 10 provides an estimate of the added value of port-related workers during the analysis period. This estimate is also based on 650,000 TEU per berth, and if the volume changes, the benefits are adjusted proportionally by the changed rate. The estimated added value of other port users is shown as a maximum of $\$ 1,761,611,307$ to a minimum of $\$ 391,469,965$.

Table 10. Total added value of other port service users (unit: U.S. dollars).

\begin{tabular}{cccccc}
\hline Year & 9 Berths & 5 Berths & 4 Berths & 3 Berths & 2 Berths \\
\hline Total & $\$ 1,761,611,307$ & $\$ 978,674,912$ & $\$ 782,937,279$ & $\$ 587,204,947$ & $\$ 391,469,965$ \\
\hline Source: Author & &
\end{tabular}

\subsection{Estimating Total Investment Costs}

Total investment costs of ACT development are largely composed of construction cost, operation cost, interest cost, reinvestment, and residual by applying Equation (16). First, construction cost is basically calculated based on the investments of the 2-5 and 2-6 piers in the west container terminal of Busan Port. Each investment amount is applied based on the finalized amount if there are execution details (completion design, etc.), and if there is no final amount, the estimated investment amount in the preliminary feasibility review report for each pier is used. In Table 11, the amount of investment per berth is from a maximum of $\$ 1,870,664,311$ to a minimum of $\$ 428,905,477$.

Table 11. Construction costs (units: U.S. dollars).

\begin{tabular}{|c|c|c|c|c|c|}
\hline & 9 Berths & 5 Berths & 4 Berths & 3 Berths & 2 Berths \\
\hline Infrastructure construction & $\$ 889,761,484$ & $\$ 494,311,837$ & $\$ 395,449,647$ & $\$ 296,587,456$ & $\$ 197,724,382$ \\
\hline Superstructure construction & $\$ 351,945,230$ & $\$ 195,524,735$ & $\$ 156,419,611$ & $\$ 117,315,371$ & $\$ 78,210,247$ \\
\hline Research and design cost & $\$ 25,992,933$ & $\$ 14,440,813$ & $\$ 11,552,120$ & $\$ 8,664,311$ & $\$ 5,776,502$ \\
\hline Incidental expenses & $\$ 46,916,078$ & $\$ 26,064,488$ & $\$ 20,851,590$ & $\$ 15,638,693$ & $\$ 10,425,795$ \\
\hline Reserve cost & $\$ 134,912,544$ & $\$ 74,951,413$ & $\$ 59,961,131$ & $\$ 44,970,848$ & $\$ 29,980,565$ \\
\hline Access road construction costs & $\$ 23,763,251$ & $\$ 23,763,251$ & $\$ 23,763,251$ & $\$ 23,763,251$ & $\$ 23,763,251$ \\
\hline $\begin{array}{l}\text { Total investment costs subject to } \\
\text { financial analysis }\end{array}$ & $\$ 1,473,291,519$ & $\$ 829,056,537$ & $\$ 667,997,350$ & $\$ 506,939,929$ & $\$ 345,880,742$ \\
\hline $\begin{array}{l}\text { Additional construction cost for } \\
\text { access road }\end{array}$ & $\$ 23,763,251$ & & & & \\
\hline CY site construction cost & $\$ 60,901,060$ & $\$ 33,833,922$ & $\$ 27,067,138$ & $\$ 20,300,353$ & $\$ 13,533,569$ \\
\hline Fairway dredging construction cost & $\$ 195,905,477$ & $\$ 108,836,572$ & $\$ 87,068,905$ & $\$ 65,302,120$ & $\$ 43,534,452$ \\
\hline Dredged soil dump construction cost & $\$ 116,803,004$ & $\$ 64,890,459$ & $\$ 51,912,544$ & $\$ 38,934,629$ & $\$ 25,956,714$ \\
\hline $\begin{array}{l}\text { Total investment costs for } \\
\text { economic analysis }\end{array}$ & $\$ 1,870,664,311$ & $\$ 1,036,617,491$ & $\$ 834,045,936$ & $\$ 631,477,032$ & $\$ 428,905,477$ \\
\hline
\end{tabular}

Source: Annual report of Busan Port Authority (2019).

The annual operating cost should be calculated by dividing it into maintenance cost and management and operation cost, but it is difficult to calculate it reasonably assuming the operation situation, so it is calculated by applying $2 \%$ of the accumulated investment for each project suggested in the Korean government guidelines [9]. The amount of annual operating expenses incurred is shown in Table 12. The total operating cost considering the berth size during the analysis period is $\$ 917,011,484$ at the maximum and $\$ 203,781,802$ at the minimum. 
Table 12. Estimated operating costs from 2020 to 2049 (units: U.S. dollars).

\begin{tabular}{cccccc}
\hline Year & 9 Berths & 5 Berths & 4 Berths & 3 Berths & 2 Berths \\
\hline Total & $\$ 917,011,484$ & $\$ 509,450,530$ & $\$ 407,560,954$ & $\$ 305,674,028$ & $\$ 203,781,802$ \\
\hline
\end{tabular}

Source: Author.

Interest costs are calculated on the assumption that the total investment amount is financed through borrowing, interest is paid at an interest rate of $3.16 \%$ [21], and the balance deducting interest for the current period from the current income is repaid from the borrowings at the end of the previous year. In Table 13, the borrowing interest rate is $3.16 \%$, which is the weighted average of the interest rate of bonds issued over the past 10 years by the Busan Port Authority.

Table 13. Weighted average cost of capital.

\begin{tabular}{|c|c|c|c|c|c|c|}
\hline Bond Name & Issue Date & $\begin{array}{c}\text { Balance of } \\
\text { Borrowings } \\
\text { (U.S. dollars) }\end{array}$ & Maturity Date & $\begin{array}{c}\text { Interest } \\
\text { Rate } \\
\text { (a) }\end{array}$ & $\begin{array}{l}\text { Weights } \\
\text { (b) }\end{array}$ & $\begin{array}{c}\text { WACC } \\
(=\mathbf{a} \times \mathbf{b})\end{array}$ \\
\hline BPA 11th bond & 09.8 .25 & $\$ 88,339,223$ & 19.8 .25 & $5.77 \%$ & 0.06 & $0.33 \%$ \\
\hline BPA 14th bond & 10.3 .26 & $\$ 44,169,611$ & 20.3 .26 & $5.05 \%$ & 0.03 & $0.14 \%$ \\
\hline BPA 15th bond & 10.5 .20 & $\$ 97,173,145$ & 20.5 .20 & $5.30 \%$ & 0.06 & $0.33 \%$ \\
\hline BPA 17th bond & 11.10 .25 & $\$ 132,508,834$ & 22.10 .25 & $4.29 \%$ & 0.08 & $0.36 \%$ \\
\hline BPA 18th bond & 12.12 .4 & $\$ 97,173,145$ & 22.12 .4 & $3.15 \%$ & 0.06 & $0.20 \%$ \\
\hline BPA 19-1st bond & 13.6.11 & $\$ 114,840,989$ & 23.6 .11 & $3.29 \%$ & 0.07 & $0.24 \%$ \\
\hline BPA 19-2nd bond & 13.6.11 & $\$ 70,671,378$ & 33.6 .11 & $3.40 \%$ & 0.05 & $0.15 \%$ \\
\hline BPA 21-1st bond & 14.8 .13 & $\$ 88,339,223$ & 24.8 .13 & $3.17 \%$ & 0.06 & $0.18 \%$ \\
\hline BPA 21-2nd bond & 14.8 .13 & $\$ 70,671,378$ & 34.8 .13 & $3.33 \%$ & 0.05 & $0.15 \%$ \\
\hline BPA 22nd bond & 16.5.24 & $\$ 88,339,223$ & 26.5.24 & $1.87 \%$ & 0.06 & $0.11 \%$ \\
\hline BPA 23rd bond & 16.7 .21 & $\$ 44,169,611$ & 26.7 .21 & $1.50 \%$ & 0.03 & $0.04 \%$ \\
\hline BPA 24-1st bond & 16.9 .6 & $\$ 79,505,300$ & 21.9 .6 & $1.49 \%$ & 0.05 & $0.08 \%$ \\
\hline BPA 24-2st bond & 16.9.6 & $\$ 176,678,445$ & 26.9.6 & $1.65 \%$ & 0.11 & $0.19 \%$ \\
\hline BPA 25th bond & 17.4.6 & $\$ 61,837,456$ & 27.4 .6 & $2.26 \%$ & 0.04 & $0.09 \%$ \\
\hline BPA 26-1st bond & 18.2 .5 & $\$ 176,678,445$ & 28.2 .5 & $2.90 \%$ & 0.11 & $0.33 \%$ \\
\hline BPA 26-2st bond & 18.2 .5 & $\$ 132,508,834$ & 38.2 .5 & $2.92 \%$ & 0.08 & $0.25 \%$ \\
\hline Total & & $\$ 1,563,604,240$ & - & & 1.000 & $3.16 \%$ \\
\hline
\end{tabular}

Source: Busan Port Authority Annual Report 2019 [21].

The amount of interest expense accrued by year is presented in Table 14. The estimated interest expense during the analysis period ranges from a maximum of $\$ 1,038,621,025$ to a minimum of $\$ 248,640,459$.

Table 14. Estimated interest costs from 2020 to 2049 (units: U.S. dollars).

\begin{tabular}{cccccc}
\hline Year & 9 Berths & 5 Berths & 4 Berths & 3 Berths & 2 Berths \\
\hline Total & $\$ 1,038,621,025$ & $\$ 571,224,382$ & $\$ 463,652,827$ & $\$ 356,117,491$ & $\$ 248,640,459$ \\
\hline Source: Author. & & &
\end{tabular}

Calculation of reinvestment and residual value assumes reinvestment at the end of its useful life, and the base price for reinvestment is assumed to be reinvested by reflecting the inflation rate from the initial investment to the time of reinvestment. The reinvestment amount accrued by year and the reversal of the residual value in the last year are as follows 
in Table 15. During the analysis period, the estimated total reinvestment amount is from a maximum of $\$ 167,710,247$ to a minimum of $\$ 37,269,435$.

Table 15. Reinvestment and residual value from 2020 to 2049 (unit: U.S. dollars).

\begin{tabular}{cccccc}
\hline Year & 9 Berths & 5 Berths & 4 Berths & 3 Berths & 2 Berths \\
\hline $2020 \sim 2033$ & - & - & - & - \\
\hline 2034 & $\$ 118,978,799$ & $\$ 66,098,940$ & $\$ 52,878,975$ & $\$ 39,659,894$ & - \\
\hline $2030 \sim 2038$ & - & - & - & - & $\$ 26,439,929$ \\
\hline 2039 & $\$ 97,463,781$ & $\$ 54,146,643$ & $\$ 43,317,138$ & $\$ 32,487,633$ & - \\
\hline $2040 \sim 22048$ & - & - & - & $(\$ 16,243,816)$ & $(\$ 10,829,505)$ \\
\hline 2049 & $(\$ 48,732,332)$ & $(\$ 27,073,322)$ & $(\$ 21,659,011)$ & $\$ 55,903,710$ & $\$ 37,269,435$ \\
\hline Total reinvestment & $\$ 167,710,247$ & $\$ 93,172,261$ & $\$ 74,537,102$ & &
\end{tabular}

\section{Discussion}

The container terminal is an important logistics facility for import/export cargo and transshipment cargo between countries and must have facilities with sufficient capacity for import and export cargo in a timely manner according to the user's request. If port facilities are oversupplied, terminal fees may fall due to excessive competition between TOCs, which could deteriorate profitability. Therefore, in the end, excessive supply expansion of port facilities intensifies price competition, not service competition, to attract cargo between TOCs. On the contrary, if there is congestion due to the lack of port facilities, the import and export trade will be disrupted as a whole. As a result, additional logistics costs due to shipping delay losses, loss of trade claims, and loss of inventory costs for shippers may appear as constraints on national economic growth. The problems faced by port stakeholders due to the excess or shortage of port facilities conflict with each other, and then the problem of inefficiency in the stevedoring market arises. Hence, it is very important to derive the proper terminal capacity because it is problematic to estimate the terminal capacity to the minimum or maximum in a situation where the problems of the port stakeholders conflict exit.

In order to find the optimal terminal capacity that brings the benefits of ACT investment through economic analysis, this study investigates the net present value (NPV) changes and break-even volume according to the change in the size of berths from the perspective of national fiscal income and national economy. In the nine-berths model (maximum berth of ACT), the positive rates of NPV are from 530,000TEU with $1.96 \%$ social discounted ratio to 590,000TEU with 3.96\% social discounted ratio, presented in Figure 3. At $2.96 \%$ of the standard discounted ratio, $550,000 \mathrm{TEU}$ has positive NPV value $(\$ 75,769)$. Thus, the proper terminal capacity from the public sector to secure the economic feasibility of ACT should be at least 530,000 TEU to 590,000 TEU or more in the nine-berth model.

In the two-berths model (minimum berth of ACT), the positive NPV rages from $570,000 \mathrm{TEU}$ with a $1.96 \%$ discounted ratio to $640,000 \mathrm{TEU}$ with $3.96 \%$, shown in Figure 4 . The proper terminal capacity of the two berths model is at least 570,000TEU, and the maximum is $640,000 \mathrm{TEU}$, which appears to increase significantly compared to the 9berth model. 


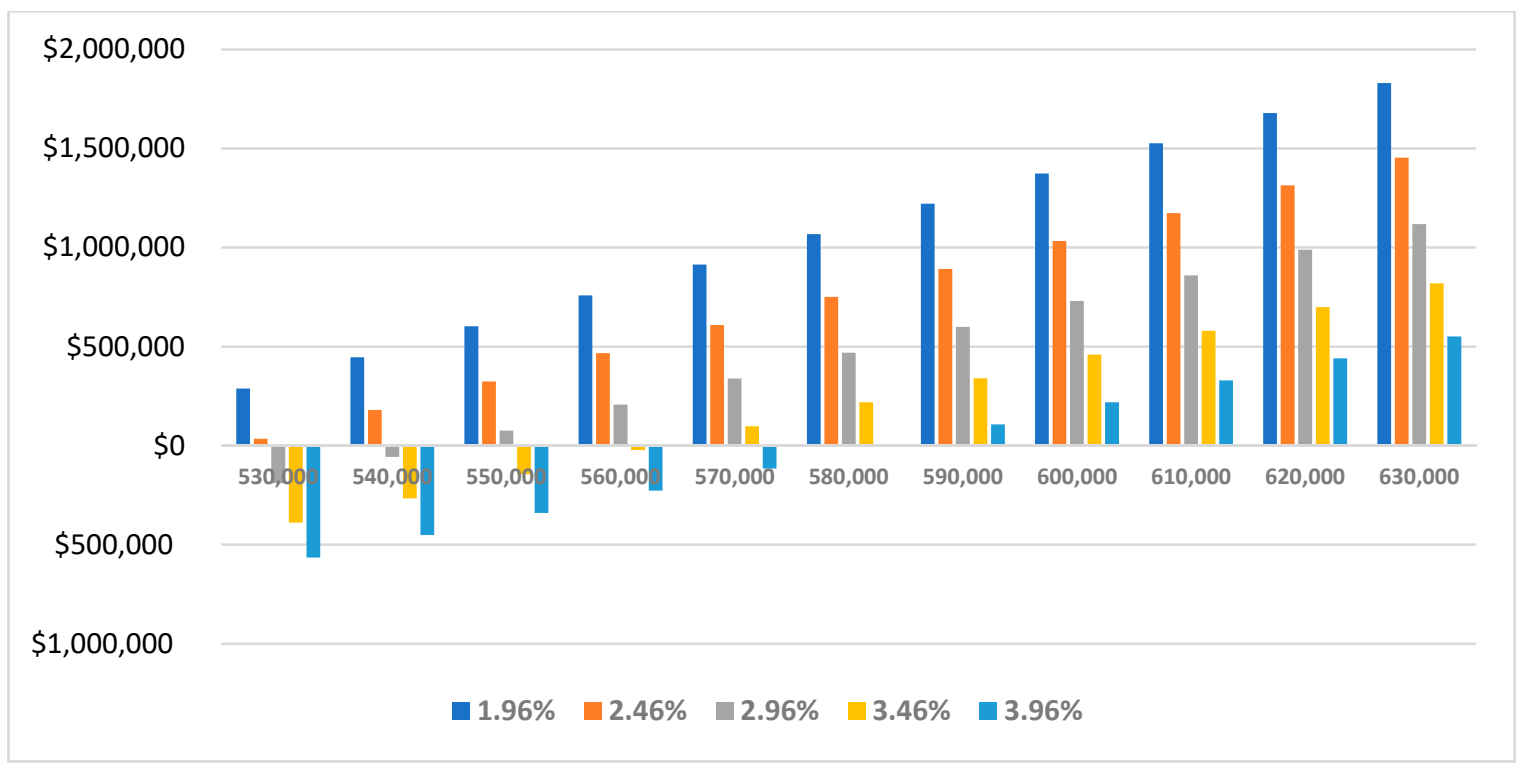

Figure 3. NPV of social discount rate changes in 9 berths.

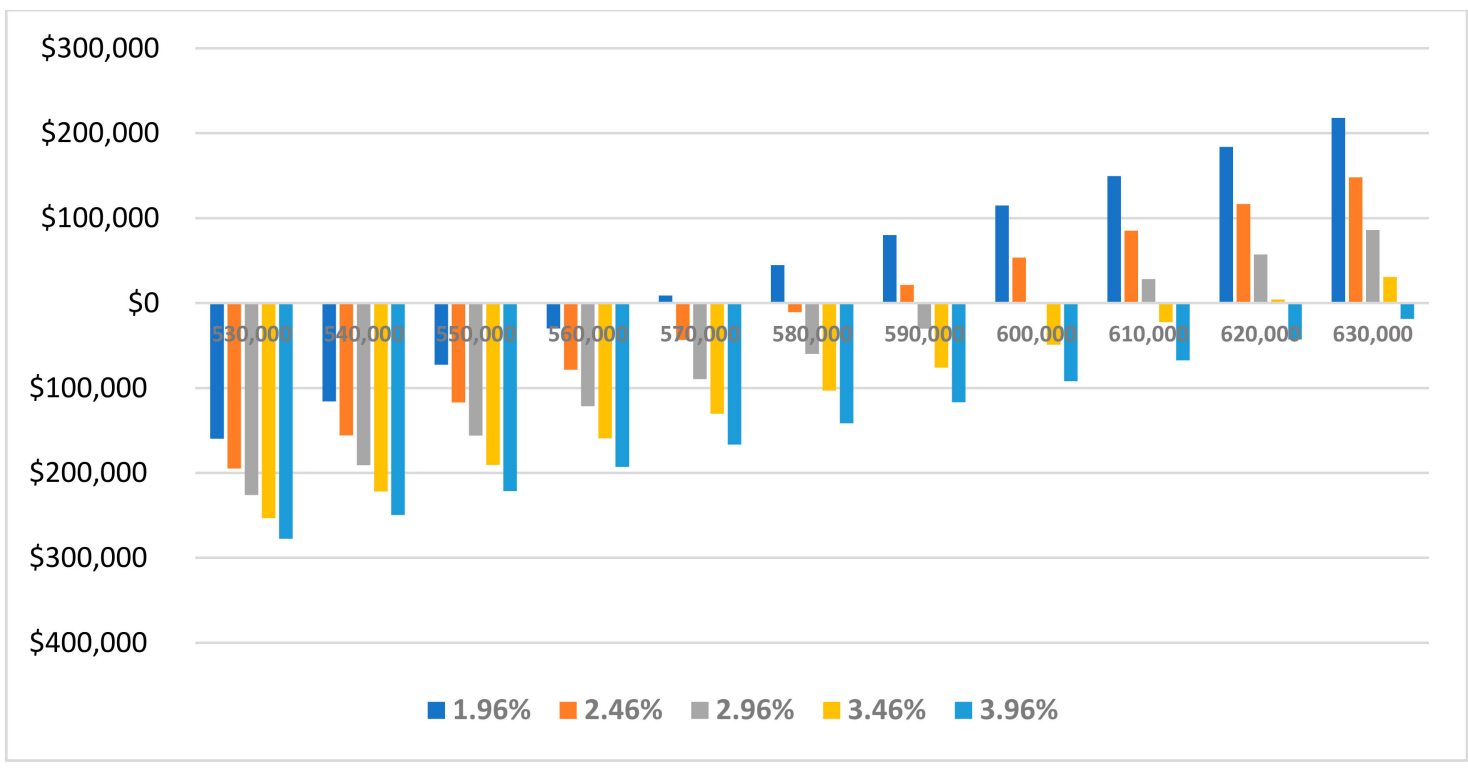

Figure 4. NPV of social discount rate changes in 2 berths.

From the perspective of the government's finances and national economy, the amount of loading/unloading that matches the amount of investment costs, income, and benefits for each berth (break-even loading/unloading volume per berth) is 544,272TEU at nine berths, 569,661TEU at five berths, 578,292TEU at four berths, 587,997TEU at three berths and $600,318 \mathrm{TEU}$ at two berths when $2.96 \%$ standard social discounted ratio is applied. Figure 5 shows NPV changes per berth size under $2.96 \%$ social discounted ratio. Under the same social discount rate, the break-even TEU is lower as the size of the berth is larger, so it can be inferred that the economy of scale is applied to the proper terminal capacity. In the sensitivity analysis that considers the changes of social discount rate and the processing quantity per berth, NPV has a positive value at the level of at least 530,000TEU (9 berths and $1.96 \%$ social discount rate) and up to $640,000 \mathrm{TEU}$ ( 2 berths and $3.46 \%$ ). In summary, the proper terminal capacity from the public sector to secure the economic feasibility of ACT should be at least 530,000 TEU to 640,000 TEU or more in considering social discounted ratio and berths. The details are referred to Appendix A Table A1. 


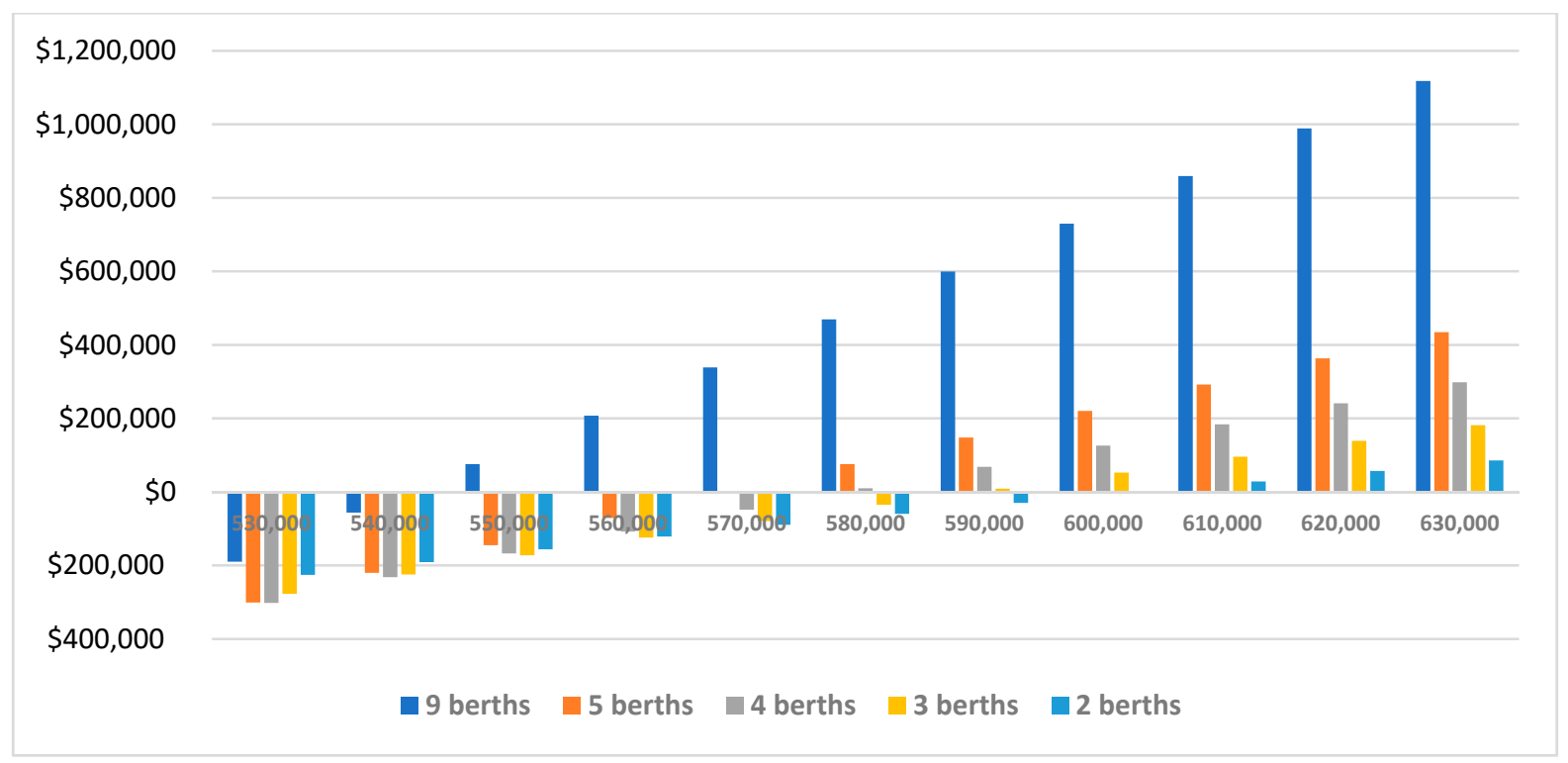

Figure 5. NPV changes per berth size in applying a 2.96\% social discount ratio (Source: Author).

\section{Conclusions}

Efficient port investment and operation are an important factor in enhancing port productivity and enhancing the competitiveness of a country pursuing an export-led economic model such as Korea, Japan, and China. In particular, with the emergence of smart ports due to the 4th industrial revolution, the port development environment has changed a lot, and it is expected that there will be more rapid changes in the future. Therefore, it is necessary to analyze the economic feasibility of considering future port development. The proper terminal capacity can be defined as the ability to create maximum efficiency and minimum cost in a close relationship with port stakeholders and to respond appropriately to changes in the internal and external environment. In this sense, this study provides a procedure that allows us to calculate the economic analysis of ACT investment based on major economic parameters. The economic analysis of the public sector regarding ACT investment calculates the proper terminal capacity by estimating benefits and costs for three sectors linked with ACT benefits.

This study conducts a case study focusing on the Busan New Port, Korea's largest container port, as well as introducing ACT. In ACT development, enormous capital investment is made by various port stakeholders, so it is necessary to analyze the economic analysis of the proper terminal capacity that can satisfy the interests of them. This study aims to define the calculation formula in a detailed level related to benefits and costs by step and to define how to apply the values of parameters on a formula based on the Korean government guideline and UNCTAD. The uniqueness of this study is that the change in NPV can be observed according to the change in the number of berths and the change in social interest rate. This study expects to provide a useful method and procedure for economic analysis in investing in ACT development.

This study estimates the analysis target period as a total of 30 years from 1 January, 2020 to 1 January, 2049. The social discount rate is $2.96 \%$, which is the rate of return on government bonds with a maturity of 5 years $(1.96 \%)$ plus the business risk premium $(1 \%)$, and the proper terminal capacity is calculated by applying a total of five berth sizes $(9,5$, 4,3 and 2 berths). As economic analysis results, the break-even terminal capacity is from $544,272 \mathrm{TEU}$ of the nine-berth model to 600,318TEU of the two-berth model in applying $2.96 \%$ social discount ratio. In a sensitivity test considering the change in the discount rate and the size of the berth at the same time, NPV has a positive value from a minimum of 530,000 TEU (9 berths with $1.96 \%$ social discount ratio) to a maximum of 640,000 TEU ( 2 berths with $3.46 \%$ social discount ratio). This result suggests that in order for the public 
sector to secure economic feasibility for ACT investment, it must have the proper terminal capacity of at least 530,000 TEU to a maximum of 640,000 TEU. In addition, as the number of berths increases, the proper terminal capacity decreases, so we confirmed that there is an economy of scale in ACT development.

In the case of port investment projects, the economic benefits arising from the characteristics of the target port are different, and thus, the applicable benefit items are also presented in a variety of ways. However, it is a reality that it depends on the decision of the researcher as to what to select for each step as a detailed item and how to apply the parameter value. Hence, this study is expected to contribute to establishing and quantifying clear standards for the benefits and costs required for economic analysis of port development. In the future, not only Busan New Port but also other ports considering the introduction of ACT, applying the economic analysis method suggested in this study is expected to be of good implication in analyzing the proper terminal capacity. However, this study does not consider technical analysis or other uncertainty parameters such as security assessment other than financial variables. Therefore, a subsequent study is expected to conduct a more comprehensive perspective suggesting the completeness of the economic analysis model can be improved. Finally, this study is a domestic study focusing on the Busan New Port, and the major parameters used for economic analysis are in line with domestic guidelines, so there is a limitation to apply overseas ACT development. Therefore, subsequent study requires the characteristics of the country in addition to the economic analysis method presented in this study.

Author Contributions: All authors equally contributed to the empirical analysis and writing. N.P. contributed to the overall idea, data collecting, and analyzing of this study. Y.A. contributed to analyzing, writing, and reviewing of this study. All authors have read and agreed to the published version of the manuscript.

Funding: This research received no external funding.

Conflicts of Interest: The authors declare no conflict of interest.

\section{Appendix A}

Table A1. NPV per berth considering changes of processing quantity and discount ratio.

\begin{tabular}{|c|c|c|c|c|c|c|}
\hline \multicolumn{7}{|c|}{ Panel A: 9-berth model (unit: U.S. dollars) } \\
\hline & & \multicolumn{5}{|c|}{ Discount ratio } \\
\hline & & $1.96 \%$ & $2.46 \%$ & $2.96 \%$ & $3.46 \%$ & $3.96 \%$ \\
\hline \multirow{11}{*}{$\begin{array}{l}\text { Throughput } \\
\text { per berth } \\
\text { (TEU) }\end{array}$} & 530,000 & $\$ 287,792$ & $\$ 34,327$ & $(\$ 189,758)$ & $(\$ 388,261)$ & $(\$ 564,464)$ \\
\hline & 540,000 & $\$ 446,233$ & $\$ 179,544$ & $(\$ 56,461)$ & $(\$ 265,721)$ & $(\$ 451,641)$ \\
\hline & 550,000 & $\$ 603,029$ & $\$ 323,426$ & $\$ 75,769$ & $(\$ 144,013)$ & $(\$ 339,447)$ \\
\hline & 560,000 & $\$ 758,852$ & $\$ 466,563$ & $\$ 207,454$ & $(\$ 22,678)$ & $(\$ 227,477)$ \\
\hline & 570,000 & $\$ 913,832$ & $\$ 609,025$ & $\$ 338,612$ & $\$ 98,258$ & $(\$ 115,795)$ \\
\hline & 580,000 & $\$ 1,067,812$ & $\$ 750,739$ & $\$ 469,240$ & $\$ 218,853$ & $(\$ 4291)$ \\
\hline & 590,000 & $\$ 1,221,181$ & $\$ 891,988$ & $\$ 599,529$ & $\$ 339,221$ & $\$ 107,084$ \\
\hline & 600,000 & $\$ 1,374,111$ & $\$ 1,032,863$ & $\$ 729,504$ & $\$ 459,326$ & $\$ 218,241$ \\
\hline & 610,000 & $\$ 1,526,400$ & $\$ 1,173,329$ & $\$ 859,272$ & $\$ 579,399$ & $\$ 329,518$ \\
\hline & 620,000 & $\$ 1,678,407$ & $\$ 1,313,505$ & $\$ 988,743$ & $\$ 699,171$ & $\$ 440,490$ \\
\hline & 630,000 & $\$ 1,829,748$ & $\$ 1,453,253$ & $\$ 1,117,996$ & $\$ 818,909$ & $\$ 551,591$ \\
\hline
\end{tabular}


Table A1. Cont.

\begin{tabular}{|c|c|c|c|c|c|c|}
\hline \multicolumn{7}{|c|}{ Panel B: 5-berth model (unit: U.S. dollars) } \\
\hline & & \multicolumn{5}{|c|}{ Discount ratio } \\
\hline & & $1.96 \%$ & $2.46 \%$ & $2.96 \%$ & $3.46 \%$ & $3.96 \%$ \\
\hline \multirow{11}{*}{$\begin{array}{l}\text { Throughput } \\
\text { per berth } \\
\text { (TEU) }\end{array}$} & 530,000 & $(\$ 79,438)$ & $(\$ 197,218)$ & $(\$ 301,050)$ & $(\$ 392,788)$ & $(\$ 474,027)$ \\
\hline & 540,000 & $\$ 18,897$ & $(\$ 108,073)$ & $(\$ 220,112)$ & $(\$ 319,186)$ & $(\$ 406,989)$ \\
\hline & 550,000 & $\$ 108,771$ & $(\$ 26,096)$ & $(\$ 145,233)$ & $(\$ 250,692)$ & $(\$ 344,242)$ \\
\hline & 560,000 & $\$ 197,433$ & $\$ 54,923$ & $(\$ 71,090)$ & $(\$ 182,742)$ & $(\$ 281,876)$ \\
\hline & 570,000 & $\$ 285,133$ & $\$ 135,184$ & $\$ 2470$ & $(\$ 115,221)$ & $(\$ 219,806)$ \\
\hline & 580,000 & $\$ 371,961$ & $\$ 214,745$ & $\$ 75,482$ & $(\$ 48,119)$ & $(\$ 158,040)$ \\
\hline & 590,000 & $\$ 457,959$ & $\$ 293,630$ & $\$ 147,952$ & $\$ 18,560$ & $(\$ 96,595)$ \\
\hline & 600,000 & $\$ 543,368$ & $\$ 372,050$ & $\$ 220,066$ & $\$ 84,976$ & $(\$ 35,333)$ \\
\hline & 610,000 & $\$ 628,125$ & $\$ 449,974$ & $\$ 291,818$ & $\$ 151,147$ & $\$ 25,784$ \\
\hline & 620,000 & $\$ 712,562$ & $\$ 527,668$ & $\$ 363,418$ & $\$ 217,234$ & $\$ 86,877$ \\
\hline & 630,000 & $\$ 796,653$ & $\$ 605,069$ & $\$ 434,773$ & $\$ 283,116$ & $\$ 147,801$ \\
\hline \multicolumn{7}{|c|}{ Panel C: 4-berth model (unit: U.S. dollars) } \\
\hline & & \multicolumn{5}{|c|}{ Discount ratio } \\
\hline & & $1.96 \%$ & $2.46 \%$ & $2.96 \%$ & $3.46 \%$ & $3.96 \%$ \\
\hline \multirow{11}{*}{$\begin{array}{l}\text { Throughput } \\
\text { per berth } \\
\text { (TEU) }\end{array}$} & 530,000 & $(\$ 138,732)$ & $(\$ 225,560)$ & $(\$ 302,094)$ & $(\$ 369,710)$ & $(\$ 429,595)$ \\
\hline & 540,000 & $(\$ 52,435)$ & $(\$ 147,913)$ & $(\$ 232,109)$ & $(\$ 306,521)$ & $(\$ 372,437)$ \\
\hline & 550,000 & $\$ 25,957$ & $(\$ 76,858)$ & $(\$ 167,605)$ & $(\$ 247,872)$ & $(\$ 319,026)$ \\
\hline & 560,000 & $\$ 97,663$ & $(\$ 11,461)$ & $(\$ 107,878)$ & $(\$ 193,244)$ & $(\$ 268,988)$ \\
\hline & 570,000 & $\$ 168,516$ & $\$ 53,273$ & $(\$ 48,648)$ & $(\$ 138,971)$ & $(\$ 219,181)$ \\
\hline & 580,000 & $\$ 238,538$ & $\$ 117,348$ & $\$ 10,071$ & $(\$ 85,080)$ & $(\$ 169,646)$ \\
\hline & 590,000 & $\$ 307,801$ & $\$ 180,808$ & $\$ 68,301$ & $(\$ 31,567)$ & $(\$ 120,395)$ \\
\hline & 600,000 & $\$ 376,422$ & $\$ 243,746$ & $\$ 126,115$ & $\$ 21,621$ & $(\$ 71,387)$ \\
\hline & 610,000 & $\$ 444,624$ & $\$ 306,358$ & $\$ 183,683$ & $\$ 74,632$ & $(\$ 22,498)$ \\
\hline & 620,000 & $\$ 512,289$ & $\$ 368,574$ & $\$ 240,976$ & $\$ 127,473$ & $\$ 26,313$ \\
\hline & 630,000 & $\$ 579,592$ & $\$ 430,494$ & $\$ 298,032$ & $\$ 180,129$ & $\$ 74,983$ \\
\hline \multicolumn{7}{|c|}{ Panel D: 3-berth model (unit: U.S. dollars) } \\
\hline & & \multicolumn{5}{|c|}{ Discount ratio } \\
\hline & & $1.96 \%$ & $2.46 \%$ & $2.96 \%$ & $3.46 \%$ & $3.96 \%$ \\
\hline \multirow{11}{*}{$\begin{array}{l}\text { Throughput } \\
\text { per berth } \\
\text { (TEU) }\end{array}$} & 530,000 & $(\$ 165,830)$ & $(\$ 224,986)$ & $(\$ 277,142)$ & $(\$ 323,242)$ & $(\$ 364,094)$ \\
\hline & 540,000 & $(\$ 100,517)$ & $(\$ 166,470)$ & $(\$ 224,619)$ & $(\$ 276,007)$ & $(\$ 321,532)$ \\
\hline & 550,000 & $(\$ 36,118)$ & $(\$ 108,523)$ & $(\$ 172,388)$ & $(\$ 228,845)$ & $(\$ 278,869)$ \\
\hline & 560,000 & $\$ 22,411$ & $(\$ 55,476)$ & $(\$ 124,235)$ & $(\$ 185,065)$ & $(\$ 239,000)$ \\
\hline & 570,000 & $\$ 76,102$ & $(\$ 6517)$ & $(\$ 79,528)$ & $(\$ 144,181)$ & $(\$ 201,557)$ \\
\hline & 580,000 & $\$ 129,142$ & $\$ 41,936$ & $(\$ 35,202)$ & $(\$ 103,570)$ & $(\$ 164,293)$ \\
\hline & 590,000 & $\$ 181,611$ & $\$ 89,940$ & $\$ 8784$ & $(\$ 63,207)$ & $(\$ 127,198)$ \\
\hline & 600,000 & $\$ 233,577$ & $\$ 137,545$ & $\$ 52,458$ & $(\$ 23,077)$ & $(\$ 90,269)$ \\
\hline & 610,000 & $\$ 285,023$ & $\$ 184,726$ & $\$ 95,794$ & $\$ 16,786$ & $(\$ 53,544)$ \\
\hline & 620,000 & $\$ 336,043$ & $\$ 231,567$ & $\$ 138,864$ & $\$ 56,449$ & $(\$ 16,962)$ \\
\hline & 630,000 & $\$ 386,731$ & $\$ 278,167$ & $\$ 181,771$ & $\$ 96,017$ & $\$ 19,583$ \\
\hline
\end{tabular}


Table A1. Cont.

\begin{tabular}{|c|c|c|c|c|c|c|}
\hline \multicolumn{7}{|c|}{ Panel E: 2-berth model (unit: U.S. dollars) } \\
\hline & & & & iscount rati & & \\
\hline & & $1.96 \%$ & $2.46 \%$ & $2.96 \%$ & $3.46 \%$ & $3.96 \%$ \\
\hline \multirow{11}{*}{$\begin{array}{l}\text { Throughput } \\
\text { per berth } \\
\text { (TEU) }\end{array}$} & 530,000 & $(\$ 159,862)$ & $(\$ 194,952)$ & $(\$ 225,918)$ & $(\$ 253,317)$ & $(\$ 277,628)$ \\
\hline & 540,000 & $(\$ 115,841)$ & $(\$ 155,713)$ & $(\$ 190,868)$ & $(\$ 221,943)$ & $(\$ 249,482)$ \\
\hline & 550,000 & $(\$ 72,572)$ & $(\$ 116,932)$ & $(\$ 156,045)$ & $(\$ 190,614)$ & $(\$ 221,242)$ \\
\hline & 560,000 & $(\$ 29,861)$ & $(\$ 78,493)$ & $(\$ 121,392)$ & $(\$ 159,319)$ & $(\$ 192,927)$ \\
\hline & 570,000 & $\$ 8767$ & $(\$ 43,468)$ & $(\$ 89,586)$ & $(\$ 130,391)$ & $(\$ 166,573)$ \\
\hline & 580,000 & $\$ 44,608$ & $(\$ 10,793)$ & $(\$ 59,755)$ & $(\$ 103,116)$ & $(\$ 141,598)$ \\
\hline & 590,000 & $\$ 79,955$ & $\$ 21,492$ & $(\$ 30,224)$ & $(\$ 76,062)$ & $(\$ 116,778)$ \\
\hline & 600,000 & $\$ 114,915$ & $\$ 53,474$ & (\$922) & $(\$ 49,177)$ & $(\$ 92,072)$ \\
\hline & 610,000 & $\$ 149,539$ & $\$ 85,189$ & $\$ 28,171$ & $(\$ 22,448)$ & $(\$ 67,478)$ \\
\hline & 620,000 & $\$ 183,883$ & $\$ 116,682$ & $\$ 57,094$ & $\$ 4154$ & $(\$ 42,972)$ \\
\hline & 630,000 & $\$ 217,996$ & $\$ 148,000$ & $\$ 85,889$ & $\$ 30,670$ & $(\$ 18,517)$ \\
\hline
\end{tabular}

\section{References}

1. Wu, Y.; Li, W.; Petering, M.E.H.; Goh, M.; de Souza, R. Scheduling Multiple Yard Cranes with Crane Interference 11 and Safety Distance Requirement. Transp. Sci. 2015, 49, 990-1005. [CrossRef]

2. Thanyaphat, M.; Kamonchanok, S. Key performance indicators of sustainable port: Case study of the eastern economic corridor in Thailand. Cogent Bus. Manag. 2019, 6, 1603275.

3. Park, N.K.; An, Y. Financial Analysis of Automated Container Terminal Capacity from the Perspective of Terminal Operating Company. J. Mar. Sci. Eng. 2020, 8, 954. [CrossRef]

4. BMBF-Internetredaktion. "Zukunftsprojekt Industrie 4.0-BMBF". 2016. Available online: https://www.bmbf.de/de/ zukunftsprojekt-industrie-4-0-848.html (accessed on 1 April 2021).

5. Lysdal, K. IContainers, The Future of Automation at Terminals and Ports. 2018. Available online: https://www.icontainers.com/ us/2018/10/09/the-future-of-automation-at-terminals-and-ports/ (accessed on 1 April 2021).

6. United Nations Conference on Trade and Development-UNCTAD. Review of Maritime Transport. 2018. Available online: https: / unctad.org/en/PublicationsLibrary/rmt2018-en.pdf (accessed on 31 March 2021).

7. Wang, N.; Chang, D.; Shi, X.; Yuan, J.; Gao, Y. Analysis and Design of Typical Automated Container Terminals Layout Considering Carbon Emissions. Sustainability 2019, 11, 2957. [CrossRef]

8. United Nations Conference on Trade and Development-UNCTAD. Appraisal of Port Investments; UN: Geneva, Switzerland, 1977.

9. Korea Development Institute. Standard Guidelines of Preliminary Feasibility Studies for Port Development, 2th ed.; KDI: Seoul, Korea, 2001.

10. Castro-Santos, L.; Bento, A.R.; Silva, D.; Salvação, N.; Guedes Soares, C. Economic Feasibility of Floating Offshore Wind Farms in the North of Spain. J. Mar. Sci. Eng. 2020, 8, 58. [CrossRef]

11. Park, S.-K.; Park, N.-K. A Study on the Estimation Model of the Proper Cargo Handling Capacity based on Simulation in Port-Port Cargo Exclusive Pier Example. J. Korea Inst. Inf. Commun. Eng. 2013, 17, 2454-2460. [CrossRef]

12. Choi, H. Current Status and Development Strategy of the Automated Container Terminal. In Proceedings of the IAPH the 5th Asian Oceania Regional Meeting, Busan, Korea, 27 March 2004.

13. McKinsey \& Company. The Future of Automated Ports. 2018. Available online: https://www.mckinsey.com/industries/traveltransport-and23logistics/our-insights/the-future-of-automated-ports (accessed on 1 April 2021).

14. Koch, T. Automated Container Terminals: Benefits for Operators and Their Clients; International Symposium Busan: Busan, Korea, 2003.

15. United Nations Conference on Trade and Development-UNCTAD. Evaluating Port Performance and Productivity; UN: Geneva, Switzerland, 1987.

16. Güler, N. Economic Evaluation of Port Investment. Pomor. Zb. 2002, 40, 205.

17. Dowd, T.J. US Container Terminal Leasing and Pricing. Marit. Policy Mgt. 1984, 11, 277-288. [CrossRef]

18. Notteboom, T. Concession Agreements as Port Governance Tools: Devolution, Port Governance and Port Performance. Res. Transp. Econ. 2006, 25, 449.

19. Ministry of Oceans and Fisheries. A Standard Construction Criteria for Port; MOF: Seoul, Korea, 2005.

20. Ministry of Oceans and Fisheries. A Study on Recalculation of Proper Port Loading Capacity; MOF: Sejong, Korea, 2020.

21. Busan Port Authority. 2019 Annual Report; BPA: Busan, Korea, 2019. 
22. Caplin, A.; Leahy, J. The social discount rate. J. Polit. Econ. 2004, 112, 1257-1268. [CrossRef]

23. Economic Statistics System. Bank of Korea. Available online: https://ecos.bok.or.kr/jsp/vis/keystat/\#/detail (accessed on 16 January 2021).

24. Kil, K.-S. Standardization of the Lease Fee Assessment System of Busan Port Container Terminals. J. Korea Port Econ. Assoc. 2011, $27,65-90$.

25. Theys, C.; Notteboom, T.; Pallis, A.A.; De Langen, P.W. The Economics behind the Awarding of Terminals in Seaports: Towards a Research Agenda. Res. Transp. Econ. 2010, 27, 37-50. [CrossRef]

26. Drewry Maritime Research. Global Container Terminal Operators; Drewry Maritime Research: London, UK, 2013.

27. BPA-Net. Busan Port Authority. Available online: https://www.chainportal.co.kr/ (accessed on 29 December 2020).

28. PETRONET. Korea National Oil Company. Available online: https://www.petronet.co.kr/v3/index.jsp (accessed on 17 January 2021).

29. KSIS. Statistics Korea. Available online: https://kosis.kr/statHtml/statHtml.do?orgId=101\&tblId=DT_1F01013 (accessed on 2 February 2021).

30. The Busan Harbor Pilot's Association. Available online: http://www.busanpilot.co.kr/information/rate (accessed on 28 December 2020). 